\title{
Impacts of Invasive Species \\ in Terrestrial and Aquatic Systems in the United States
}

\author{
Albert E. Mayfield III, Steven J. Seybold, Wendell R. Haag, \\ M. Tracy Johnson, Becky K. Kerns, John C. Kilgo, \\ Daniel J. Larkin, Rima D. Lucardi, Bruce D. Moltzan, \\ Dean E. Pearson, John D. Rothlisberger, Jeffrey D. Schardt, \\ Michael K. Schwartz, and Michael K. Young
}

\subsection{Introduction}

The introduction, establishment, and spread of invasive species in terrestrial and aquatic environments is widely recognized as one of the most serious threats to the health, sustainability, and productivity of native ecosystems (Holmes et al. 2009; Mack et al. 2000; Pyšek et al. 2012; USDA Forest Service 2013). In the United States, invasive species are the second leading cause of native species endangerment and extinction, and their costs to society

A. E. Mayfield III ( $\square)$

U.S. Department of Agriculture, Forest Service, Southern Research Station, Insects, Diseases and Invasive Plants of Southern Forests, Asheville, NC, USA

e-mail: albert.e.mayfield@usda.gov

S. J. Seybold

U.S. Department of Agriculture, Forest Service, Pacific Southwest

Research Station, Davis, CA, USA

W. R. Haag

U.S. Department of Agriculture, Forest Service, Southern Research Station, Center for Bottomland Hardwoods Research,

Frankfort, KY, USA

M. T. Johnson

U.S. Department of Agriculture, Forest Service, Pacific Southwest Research Station, Institute of Pacific Islands Forestry, Volcano, HI, USA

B. K. Kerns

U.S. Department of Agriculture, Forest Service, Pacific Northwest Research Station, Corvallis, OR, USA

J. C. Kilgo

U.S. Department of Agriculture, Forest Service, Southern Research Station, Center for Forest Watershed Research,

New Ellenton, SC, USA

D. J. Larkin

Department of Fisheries, Wildlife and Conservation Biology and the Minnesota Aquatic Invasive Species Research Center,

University of Minnesota, St. Paul, MN, USA have been estimated at $\$ 120$ billion annually (Crowl et al. 2008; Pimentel et al. 2000, 2005). These costs include lost production and revenue from agricultural and forest products, compromised use of waterways and terrestrial habitats, harm to human and animal health, reduced property values and recreational opportunities, and diverse costs associated with managing (e.g., monitoring, preventing, controlling, and regulating) invasive species (Aukema et al. 2011; Pimentel et al. 2005). The national significance of these economic, ecological, and social impacts in the

R. D. Lucardi

U.S. Department of Agriculture, Forest Service, Southern Research Station, Athens, GA, USA

B. D. Moltzan

U.S. Department of Agriculture, Forest Service, State and Private Forestry, Forest Health Protection, Washington Office, Washington, DC, USA

D. E. Pearson

U.S. Department of Agriculture, Forest Service, Rocky Mountain Research Station, Missoula, MT, USA

Ecology and Evolution, Division of Biological Sciences, University of Montana, Missoula, MT, USA

J. D. Rothlisberger

U.S. Department of Agriculture, Forest Service, Washington Office, Washington, DC, USA

J. D. Schardt

Florida Fish and Wildlife Conservation Commission, Thomasville, GA, USA

M. K. Schwartz

U.S. Department of Agriculture, Forest Service, National Genomics Center for Wildlife and Fish Conservation, Missoula, MT, USA

M. K. Young

U.S. Department of Agriculture, Forest Service, Rocky Mountain Research Station and National Genomics Center for Wildlife and Fish Conservation, Missoula, MT, USA 
United States has prompted various actions by both legislative and executive branches of the Federal Government (e.g., the Nonindigenous Aquatic Nuisance Prevention and Control Act of 1990; the Noxious Weed Control and Eradication Act of 2002; Executive Order 13112 of 1999, amended in 2016).

Because the concept of impact is inevitably influenced by human perceptions and biases, the scientific literature often characterizes the environmental effects of invasive species in terms of "ecological impacts." Ecological impacts refer to measurable changes to the properties of an ecosystem, which may be considered positive or negative depending on context (Ricciardi et al. 2013). In this chapter, we consider invasive species as a subset of non-native species that substantially affect the composition, structure, or function of native populations, communities, or ecosystems, and particularly impact these systems in a manner that decreases the ecosystem values and services (e.g., economic, aesthetic, and/or social benefits) that they provide to humans (NISC 2005; Pejchar and Mooney 2009; Walsh et al. 2016). To more effectively manage invasive species and mitigate their negative impacts on native systems, a better understanding of the nature of their ecological impacts and the mechanisms that underlie the impacts is needed.

\subsubsection{Conceptualizing Mechanisms of Invasive Species Ecological Impacts}

The classic model developed by Parker et al. (1999), in which the impact of an invasive species is a function of its range, abundance, and per capita effect, has provided a basic conceptual framework for quantifying impacts, but it has rarely been applied to specific systems (Pearson et al. 2016a; Thiele et al. 2010). A more highly synthetic framework for understanding the full range of invader impacts remains elusive (Ricciardi et al. 2013), though approaches for broad categorization of impacts have been proposed (Blackburn et al. 2014). Here, we draw from basic community ecology concepts to characterize the mechanisms and processes by which invasive species impact native systems (Fig. 2.1). Because invasive predators, pathogens, consumers, decomposers, and primary producers impact native species through different mechanisms (Fig. 2.1), and impacts can manifest differently in aquatic and terrestrial systems (Cox and Lima 2006; Moorhouse and Macdonald 2015), in this chapter, we review invasive species ecological impacts taxonomically by invasive plants, pathogens, invertebrates, and vertebrates in terrestrial and aquatic systems in the United States. Examples of the consequences of several specific invasive species are highlighted in boxes accompanied by figures.

\subsubsection{Direct and Indirect Impacts: Density- Mediated vs Trait-Mediated}

Invasive species may affect native organisms positively or negatively through direct and indirect interactions that are transmitted through density- or trait-mediated mechanisms (Fig. 2.1). These interactions may ultimately affect native organisms at multiple ecological levels, i.e., organisms, populations, communities, and ecosystems (e.g., Wootton and Emmerson 2005). Direct negative impacts of invasive species include effects on the abundance, distribution, or function of native species through predation (including, for our purposes, infection, herbivory, or parasitism) or competition for resources with potentially lasting and profound changes to native biodiversity (Allen et al. 2004, 2015; Blackburn et al. 2014; Crowl et al. 2008; Wagner and Van Driesche 2010).

Direct impacts of invaders are often obvious, such as when they damage, kill, consume, or overgrow native species, but cryptic indirect effects can be similarly powerful (White et al. 2006). Density-mediated indirect interactions arise when the invader alters the abundance of a native species, and this, in turn, alters the abundance of other native species via interaction chains (e.g., Ortega et al. 2006). Traitmediated indirect interactions (also referred to as interaction modifications (Wootton 1994)) arise when the invader alters interactions between species (two natives or a native and a non-native) in ways that change how strongly those species interact, i.e., the per capita interaction strength (e.g., Pearson 2010). Such changes arise because the invader changes the traits (phenology, morphology, or behavior) rather than the abundance of the intermediate species in ways that alter the interaction strength between the invader and the receiver species. For example, an invasive predator may kill some individuals in a native herbivore's population (a densitymediated direct effect), which could reduce foraging on its preferred forage plant (a density-mediated indirect effect), but it could also alter the herbivore's behavior (trait effect) due to predator avoidance such that the whole herbivore population dramatically reduces its impacts on its preferred plant by shifting its foraging to other plant species (trait-mediated indirect interaction; e.g., Schmitz et al. 1997). Although trait-mediated indirect interactions are more cryptic than density-mediated pathways, studies in native systems indicate that they are ubiquitous and frequently as strong as or stronger than density-mediated interactions (Schmitz et al. 2004; Trussell et al. 2006; Werner and Peacor 2003).

Other mechanisms by which invasive species impact native systems further illustrate the cryptic or complex nature of their effects. In some systems, impacts can be transmitted genetically as non-native species alter the gene pools of native species via introgression (Lockwood et al. 2007), or initial invasions may facilitate additional invaders with 


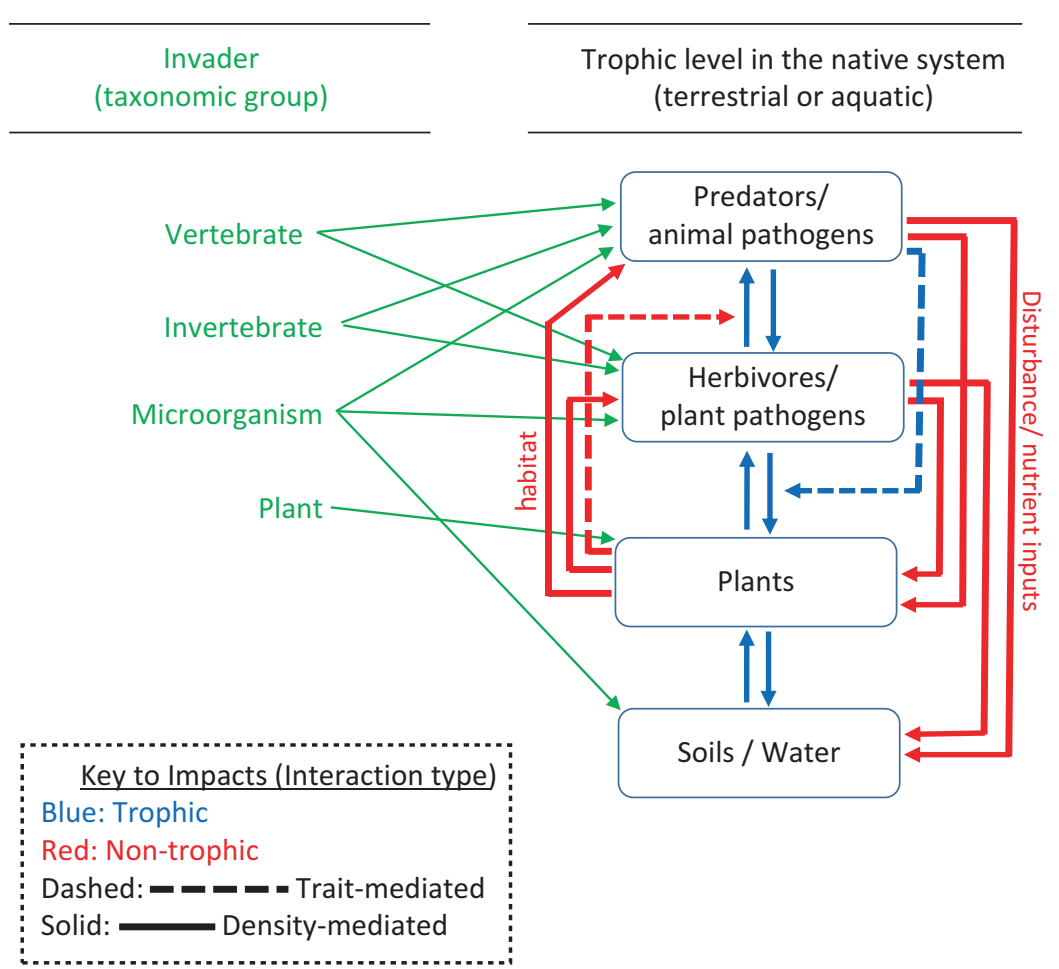

Fig. 2.1 Conceptual diagram illustrating how differences among invader taxa or functional roles determine how invasive species impact native systems. Trophic interactions are depicted as simplified food webs (blue arrows) integrated with non-trophic interactions (red arrows). Solid arrows indicate density-mediated effects, whereas dotted arrows indicate trait-mediated effects (interaction modifications). Only a subset of possible interactions are highlighted for simplicity. Invaders from various taxonomic groups (green) enter the functional network from the left. For example, in this framework, an invasive terrestrial

cascading ecological effects, referred to as invasional meltdown (Gandhi and Herms 2010a; Simberloff and Von Holle 1999). Because of their complexity, attempting to mitigate invader impacts without sufficient understanding of the impact mechanism and community context can result in serious unintended consequences (Bergstrom et al. 2009; Boettner et al. 2000; Pearson et al. 2016b; Zavaleta et al. 2001).

\subsubsection{Understanding Invaders in a Community Context}

A single invasive species can exhibit very different behaviors in different communities (Zenni and Nuñez 2013). Hence, it is critical to understand invader traits in the context of the invaded community in order to characterize its impacts (Kolar and Lodge 2001; Pyšek et al. 2012). In general, the novelty of a species relative to other community members influences whether it contributes uniquely to community function and productivity, or perhaps serves more redundantly as a buffer against disruptive forces (e.g., Duffy 2002). vertebrate that enters the system as a predator can impact native herbivores directly through food web interactions, but it can only affect native plants indirectly via either density-mediated or trait-mediated indirect interactions. The predator could, however, impact native plants and soils directly through non-trophic interactions such as disturbance or nutrient inputs. The predator can also impact other predators on the same trophic level (interactions not highlighted here) via interference (direct) or resource competition (indirect), thereby initiating indirect effects on native species at lower trophic levels

For example, the introduction of predators, consumers, or plants to islands where they represent novel functions frequently results in dramatic impacts (Pyšek et al. 2012; Simberloff 1995; Vitousek 1990). Research indicates that evaluating the novelty of an invader's traits relative to the recipient community can explain which native species will be affected and how (Ortega et al. 2014; Pearson 2009). Not surprisingly, invaders that act as ecosystem engineers (i.e., organisms that modify the availability of resources to other species by causing physical state changes in biotic or abiotic materials; Jones et al. 1996) or impact native ecosystem engineers can alter community context with substantial impacts across many species and ecological levels (e.g., Blackburn et al. 2014; Crooks 2002; Pearson 2010; Rodriguez 2006; White et al. 2006).

While an invader's novelty has clear ramifications for its ability to enter a community and impact natives when the invader represents a separate trophic level (e.g., an established invasive predator can readily impact native prey where no predators previously existed), novelty of invaders has presented a conundrum as it relates to understanding impacts within trophic levels (MacDougall et al. 2009). On one hand, 
an invading species that is unique should have an advantage in entering a community as it should experience minimal niche overlap with and resistance from native species, but if it has minimal niche overlap, how does it impact natives within the same trophic level? On the other hand, if it exhibits high niche overlap with natives, how does it enter the community? Application of coexistence theory to invasions demonstrates how invaders with high or low niche overlap with natives can invade and impact native communities as a function of the interplay between their fitness and niche differences with the natives (MacDougall et al. 2009).

\subsubsection{Research Gaps for Understanding Ecological Impact}

There are several research needs or gaps in our understanding of the impacts of invasive species on terrestrial and aquatic systems. Invader impacts can be quantified as $I_{\text {impact }}=R_{\text {range }} \times A_{\text {abundance }} \times E_{\text {per capita effect }}$ (Parker et al. 1999), but this approach has rarely been applied quantitatively due to the challenges associated with estimating per capita effects (i.e., the effect per individual or per biomass unit) of invaders within native communities (Barney et al. 2013; Pearson et al. 2016a; Ricciardi et al. 2013). Although this is a model that largely assumes a linear impact (see below) that is invariant over space and time, there may be conceptual value in attempting to apply this approach to other invasive taxa besides plants, for which it was developed. Evaluating impacts that involve multiple invaders at regional scales can be critical for prioritizing invasive species management (Chap. 7). However, most work quantifying invader impacts has been invader-specific and focused on local scales (Hulme et al. 2013). Since most systems experience multiple invaders (Kuebbing et al. 2013), understanding the additive and interactive effects of invaders, including invasional meltdown, will be a key research need for understanding overall invader impacts.

Furthermore, very few studies have examined regional impacts, especially for multiple invaders, and these have usually (but not exclusively) examined the impacts of invasive plants (Morin and Liebhold 2015; Pearson et al. 2016a; Thiele et al. 2010). These studies indicate that invader impacts are highly variable, and they may be linear or nonlinear as a function of invader abundance, and depending in part on the selection of a response metric, e.g., native abundance versus diversity (Barney et al. 2013; Pearson et al. 2016a; Thiele et al. 2010). Nonlinear impacts can result in thresholds that complicate quantification and, ultimately, management of invader impacts, but nonlinearities can be addressed (Thiele et al. 2010; Yokomizo et al. 2009). Hence, understanding how invader abundance relates to impact for different response metrics is another important research gap.
Building on the impact models of Parker et al. (1999) and Ricciardi (2003), Lockwood et al. (2007) suggested that accounting for variable success of the invader at different stages in the invasion process (e.g., transport, introduction, establishment, or spread) is important for determining overall impact. Thus, time since introduction is a significant factor when assessing impact of an invasive species. In addition to the complex mix of contributing factors such as species characteristics, environmental site characteristics, ecological interactions, and invasion history, our interpretations of impact are also shaped inevitably by human biases and limits on scientific perception and detection (Lockwood et al. 2007).

Community interactions are context dependent as are invasion outcomes (Cox and Lima 2006; Kolar and Lodge 2001). Hence, anthropogenic changes such as nitrification, increasing temperature, increasing carbon dioxide $\left(\mathrm{CO}_{2}\right)$, and increased or altered disturbance regimes can have large ramifications for invasion outcomes and invader impacts (Walther et al. 2009). Invader impacts may also change over time as a function of increasing invader abundance, cumulative effects, or changing soil feedbacks (e.g., Lankau et al. 2009). Additionally, management strategies intended to mitigate the effects of invasive species (Chap. 7) may themselves result in undesired effects by way of complex interactions or simple side effects of management tools (Bergstrom et al. 2009; Boettner et al. 2000; Pearson et al. 2016b; Zavaleta et al. 2001), resulting in a need to better understand and mitigate against these unintended effects. In order to move beyond speculation to more predictive science regarding invasive species impacts, we need to advance research in all of the areas addressed above. In the following sections, we outline current understandings of the state of the science regarding mechanisms of invader impacts by taxonomic group, highlighting key information needs for invasive plants, pathogens, invertebrates, and vertebrates in terrestrial and aquatic systems.

\subsubsection{Key Findings}

- Invasive species are a subset of non-native organisms that substantially alter composition, structure, or function of native terrestrial and aquatic systems. Their ecological impacts can include direct and indirect effects at multiple levels (organisms, populations, communities, and ecosystems). Invasive species can also impact the genetic makeup of native species populations.

- Invasive species impacts may be considered positive or negative depending on the environmental context, the stage of the invasion process, and human biases and perceptions. Nonetheless, invasive species can cause large negative ecological impacts in ways that decrease the 
economic, aesthetic, and social benefits of native ecosystems and cost taxpayers billions of dollars annually.

- The distribution, abundance, and per capita effects of invasive species are primary determinants of their ecosystem impacts. However, predicting or quantifying these impacts is difficult due to differences among organisms, their environments, and the numerous complex interactions among organisms and their environments.

- Attempts to manage invasive species can have unintended negative consequences when those complex interactions are poorly understood. Therefore, the potential consequences of applicable management options (including decisions to refrain from treatment efforts) should be considered when developing any pest management plans.

\subsubsection{Key Information Needs}

- Quantitative assessments of the ecological effects of a much wider variety of plants, animals, and pathogens would help to provide more comprehensive and accurate estimates of invasive species impact.

- Better characterization of large-scale, regional impacts of invasive species, including co-occurring impacts of multiple invaders, is needed for prioritizing invasive species management.

- When comparing impact of different invasive species, scientists should account for potential differences in invader abundance, the stage of the invasion, the type of ecosystem, and the type of impact measurements used.

- Research aimed at an understanding of how control of an invasive species affects the whole ecosystem will help avoid undesired, nontarget impacts of management.

\subsection{Impacts of Invasive Plants in Terrestrial Systems}

\subsubsection{Invasive Plant Impacts on Community Structure and Function}

Invasive plants impact native terrestrial systems by altering species abundances and distributions, fire regimes, belowground biotic and abiotic processes, and resource availability to other taxa. Impacts caused by invasive plants may differ from those caused by other invasive taxa in several ways. As autotrophs, invasive plants alter the base of the food chain and thereby key processes like primary productivity and nutrient cycling. By disrupting these basic processes, invasive plants can restructure extant ecological interactions and alter future trajectories of the community (Didham et al. 2007). Furthermore, all plants act as ecosystem engineers to varying degrees because plants provide habitats for animals and arenas for their interactions, thus impacting animals through various non-trophic and trophic pathways (Crooks 2002).

As with other invaders, key components of impact by invasive plants include the strength of their interaction with native species and their novelty in the system (i.e., the degree to which the invasive species brings new traits or functional roles). While invasive plants that are similar in form and function to native species can impact systems, those with novel traits frequently change the way systems function (Crooks 2002; Li et al. 2015; MacDougall et al. 2009) (Fig. 2.2). Recent studies that have quantified invasive plant impacts (Pearson et al. 2016a; Thiele et al. 2010) based on Parker et al.'s (1999) framework (see Sect. 2.1) demonstrate that the local abundance of the invader is a critical factor in determining the strength of plant invader impacts on native plant abundance. Accordingly, plant traits that favor increased local abundance are key to driving local impacts such as clonality, resource reallocation to larger body size, and/or release from natural enemies (Blossey and Nötzold 1995; Pyšek and Richardson 2008; Rejmánek 1996; Suda et al. 2015). Furthermore, traits linked to spread, such as increased fecundity and dispersal, facilitate the dissemination of those impacts over larger spatial scales only for species that can achieve high local abundance (Pearson et al. 2016a). In this regard, plants are unique in that polyploidy events (the nuclear accumulation of multiple sets of chromosomes) are not always fatal (as they are in animals) and can be associated with the development of traits such as larger body size or increased seed production. Historically, analyses attempting to predict invader impacts based on plant traits alone have met with limited success (Pyšek et al. 2012). However, distinguishing between traits associated with invasiveness (the effectiveness of the invader at establishing populations over wide areas) versus impact (the actual effect of the

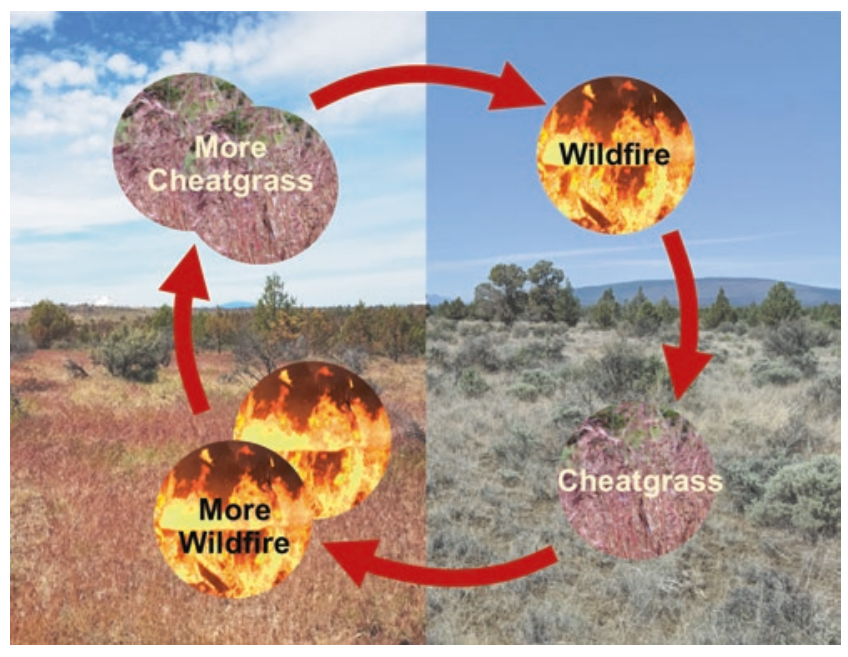

Fig. 2.2 Schematic of the grass-fire cycle 
invader on native species or systems) may improve prediction of both invasiveness and impact, particularly if invader traits are evaluated relative to the context of the recipient community (see Pearson et al. 2016a).

\subsubsection{Invasive Plants: Competition and System Engineering}

One of the most direct ways in which invasive plants impact native plants is through resource competition. According to competition theory, the plant predicted to win in head-tohead resource competition will be the species that can utilize a limiting resource at lower resource levels than its competitor (Tilman 1982). Different life history strategies and associated trait sets will generate cost-benefit tradeoffs that favor different individuals or species under different resource and environmental conditions (Grime 1988). Research indicates that increased availability of a limiting resource tends to favor invaders, whereas decreased resource availability can favor natives (Daehler 2003; Seabloom et al. 2015). Accordingly, directional anthropogenic changes to the environment (e.g., nitrification, elevated $\mathrm{CO}_{2}$, and associated climate change, altering disturbance regimes) can favor invasive plants when they increase availability of limiting resources but favor natives when they reduce limiting resources. We need to better understand how limiting resources affect invasive plant impacts on natives particularly in the context of human-caused environmental change to understand and predict the effects of invasions in the context of directional anthropogenic change.

Disturbances, whether natural or anthropogenic, are often important facilitators of invasion (Davis et al. 2000). For example, when a large, mature tree falls in an uninvaded forest (a natural disturbance), the light availability to the ground increases and mineral soil may be moved or exposed, providing an opportunity for an invading plant to establish (Colautti et al. 2006; Hierro et al. 2005). In such a scenario, the success of the plant invader is often attributed more to ruderal traits associated with establishment as compared to competitive traits (ideal weed hypothesis, Baker and Stebbins 1965; Rejmánek and Richardson 1996). Alternatively, some forests and prairies require regular intervals of disturbance to flourish and maintain their biodiversity, and thereby the community's ability to resist or minimize the establishment and impact of invasion by terrestrial plants (biotic resistance hypothesis, Elton 1958). For example, in the Southeastern United States, the land area in longleaf pine (Pinus paulustris) savannahs, characterized by widely spaced trees and sparse grassy understory, has been critically reduced due to human land-use changes and fire suppression (Landers et al. 1995). The resulting lack of low- to moderate-intensity fires has led to population reductions for a federally endangered keystone species, the gopher tortoise (Gopherus polyphemus), whose burrows serve as shelter for more than 330 other animal species (Van Lear et al. 2005). Plant invasions in this system contribute to thick understories, outcompeting fireadapted native plant species, displacing or extirpating species like the gopher tortoise, and altering the vertical and trophic structure, negatively impacting the system.

Allelopathy, the chemical inhibition of one species by another, is another means by which invasive plants can directly impact native plants (Callaway and Aschehoug 2000). Many high-impact invaders are purported to produce allelopathic compounds that potentially impact native plants (Hierro and Callaway 2003). However, studies demonstrating allelopathic effects of invasive plants in natural conditions are uncommon (Hierro and Callaway 2003), and more definitive work is required to understand how this mechanism functions and the degree to which it can explain invasive plant impacts (Blair et al. 2006).

Ecosystem engineering is an extremely important means by which invasive plants can impact native plants, animals, and system processes (Crooks 2002). Plant litter deposition and turnover rates can substantially influence abiotic conditions and biotic interactions (Xiong and Nilsson 1999). Invasive plants can differ substantially in litter production and decomposition rates from natives due to differences in growth rates and tissue composition (Allison and Vitousek 2004; Holly et al. 2009; Liao et al. 2008), and these differences likely contribute to invader impacts at multiple ecological scales (Ashton et al. 2005). Alterations in litter production and decomposition rates can also modify fire regimes in plant communities by increasing the frequency or intensity of fire events, or suppressing fire events in fireadapted communities. For example, cogongrass (Imperata cylindrica) is a well-established and widespread invasive grass across the southern Gulf Coast, and now Atlantic States, due to multiple introductions with a proportionally high degree of introduced genetic variation and intrinsic phenotypic plasticity (Lucardi et al. 2014). Cogongrass infestations increase leaf-litter production (Holly et al. 2009; Terry et al. 1997), promoting more frequent, intense fire events that result in significant timber loss and monotypic stands (Lippincott 2000; MacDonald 2004). Serious modifications in fire frequency impact both ecological and human values and tend to form positive feedback cycles with large-scale negative effects and long-term consequences (Brooks et al. 2004; D'Antonio and Vitousek 1992).

Invaders that alter fire regimes are recognized globally as some of the most important ecosystem-altering species on the planet (Box 2.1) (Balch et al. 2013; Brooks et al. 2004; D'Antonio and Vitousek 1992; Estrada and Flory 2015). Positive feedback cycles related to invasive grasses and disturbances are noted for invasive grasses such as cheatgrass (Bromus tectorum) and other annual grass species in the 


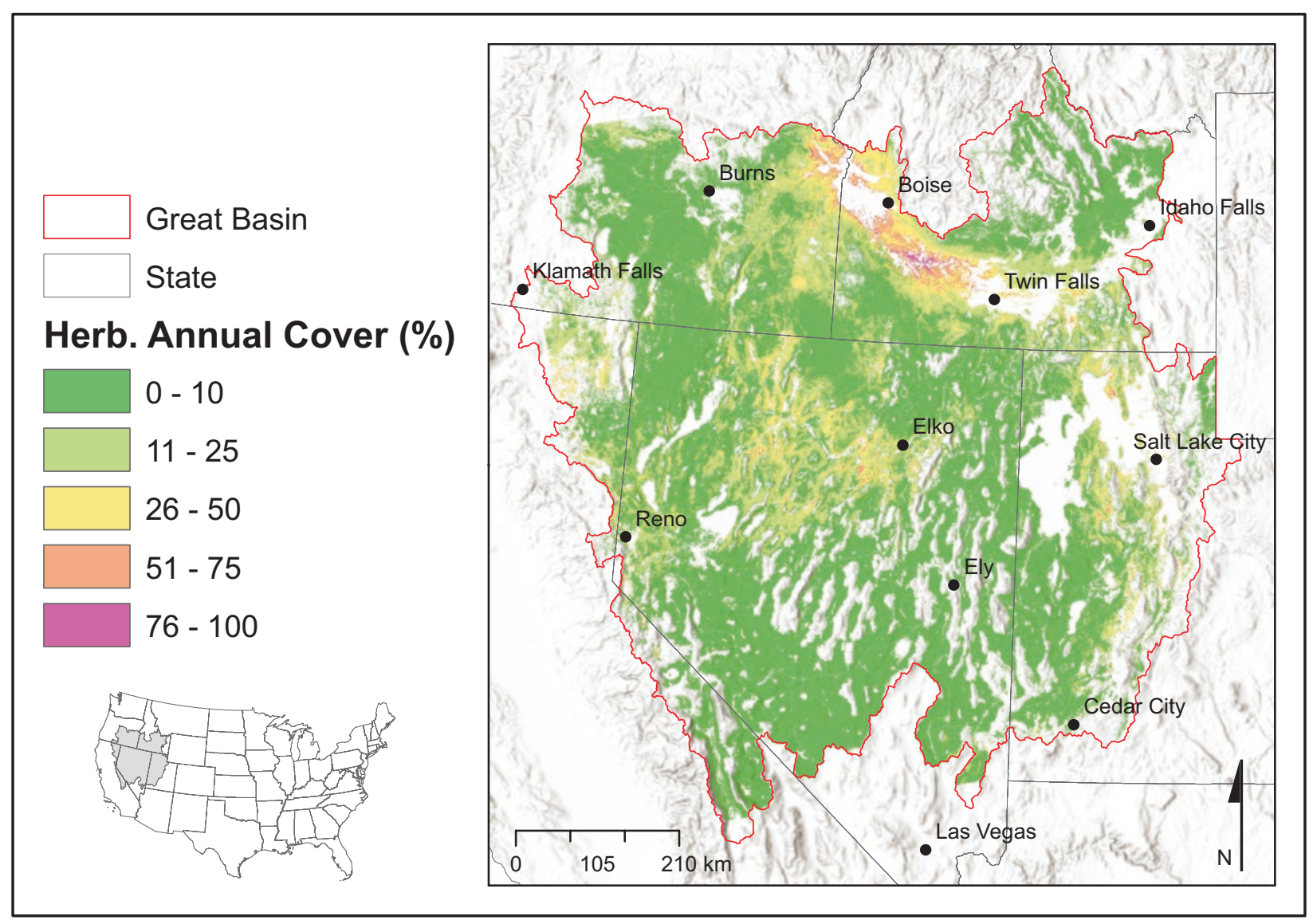

Fig. 2.3 Early 2017 season (May 1) annual herbaceous cover in the Great Basin. (Boyte and Wylie 2017)

Western United States (Fig. 2.3), buffelgrass (Pennisetum ciliare) in the Southwestern United States, and cogongrass in the Southeastern United States (see also the Northwest, Southwest, and Southeastern and Caribbean Regional Summaries in the appendix). These grass invaders initially fill the interspaces between native plants and provide horizontal continuity that can fuel fires that would typically not carry well due to the natural fuel limitations of many of these systems. These species can also dry out earlier in the season than native plants, creating a dangerous fire hazard. After fire, annual grasses may invade and exclude native species. At fine spatial scales, cheatgrass establishment in areas with cheatgrass in the vicinity is correlated with burn extent (Kerns and Day 2017). The "grass-fire" cycle can drive an ecosystem further from its original state and may eventually lead to a novel ecosystem that has no historical analog (Box 2.1). Increased fire occurrence, intensity, and severity have been observed in association with these types of grass invasions across the globe (Balch et al. 2013). For example, one fire history study in Idaho estimated a fire return interval of 3-5 years in cheatgrass-dominated rangelands, compared with 60-100 years in native sagebrush (Artemisia spp.)dominated rangelands (Whisenant 1990).
Plant-soil feedbacks are an important indirect interaction by which invasive plants impact native plants. Plant-soil interactions can result in positive or negative feedbacks between plants and soil microbial communities (Wolfe and Klironomos 2005). Pathogenic soil microbes can negatively affect plants by attacking them directly. Soil microbes can positively affect plants by increasing nutrient availability or uptake, usually via a symbiotic mycorrhizal relationship wherein the plant reciprocates by providing carbon to the microbes. Plant-soil feedbacks occur when plants or soil microbial communities influence these interactions, for example, when plants generate litter, carbon, or secondary compounds that influence the relative abundance of pathogenic versus symbiotic microbes in ways that affect their own populations or those of neighboring plant species (Wolfe and Klironomos 2005). Different species of invasive plants associate with different species or functional groups of soil microorganisms that alter plant-soil feedback after invasion. For instance, garlic mustard (Alliaria petiolate) is nonmycorrhizal and may impact natives by depleting mycorrhizal inoculum to the detriment of native host plants (Stinson et al. 2006). Also, mycorrhizal fungi that are introduced with invasive plants may enhance those plants' abilities to spread (Dickie et al. 2010; Schwartz et al. 2006; Urcelay et al. 


\section{Box 2.1 Invasive Grasses and the Grass-Fire Cycle: Saving} the Sagebrush Biome

Invasion by grass species following fire and other disturbances can promote strong feedbacks. In the case of fire, this process is frequently referred to as the "grass-fire cycle" (Fig. 2.2). Once a system is dominated by invasive grasses, e.g., cheatgrass (Bromus tectorum) or buffelgrass (Pennisetum ciliare), restoration or rehabilitation may be difficult or prohibitively expensive to accomplish, especially across large spatial scales. Emergent risks of habitat degradation due to invasive-dominated grasslands that readily burn are now widely recognized. Cheatgrass invasion and the grass-fire cycle are now known to be one of the primary mechanisms altering contemporary sagebrush (Artemisia spp.) ecosystems of the Great Basin and the sagebrush biome (Chambers et al. 2013).

The Sagebrush Biome of the Western United States: An Imperiled Ecosystem

The Great Basin of Western North America is a large (541,727 km²; Coates et al. 2016), cold desert ecosystem dominated by sagebrush shrubs (Fig. 2.3). This sagebrush steppe ecosystem has long been included among the most imperiled in North America (Noss et al. 1995), and it provides a case study of how altered wildfire regimes driven by invasive grass can rapidly change a fragile regional ecosystem and threaten native habitats and sensitive species. Much of the Great Basin has been invaded to some extent by annual grasses such as species in the genus Bromus, medusahead (Taeniatherum caput-medusae), and ventenata (Ventenata dubia) (Fig. 2.3). While other factors such as climate change, conifer expansion, land-use change, and development have been important, the spread of non-native invasive plant species is one of the major and persistent threats in these ecosystems (Chambers et al. 2017; Coates et al. 2016; Davies et al. 2011).

Much of the sagebrush biome is home to the greater sage-grouse (Centrocercus urophasianus), a large gallinaceous bird that requires distinct sagebrush habitats to survive. Populations of sage-grouse have declined in concert with the overall loss and fragmentation of the sagebrush biome following Euro-American settlement of the Western United States. The species is estimated to occupy about half of its historic distribution (Schroeder et al. 2004).

Owing to the population decline of the greater sagegrouse, several evaluations for protection under the Endangered Species Act have been conducted. While the species has not been listed, population declines have motivated unprecedented multi-agency coordinated Federal land management and An Integrated Rangeland Fire Management Strategy (IRFMS) (U.S. Department of Interior 2015). The IRFMS outlines longer term actions needed to implement policies and strategies for preventing and suppressing rangeland fire and restoring rangeland landscapes affected by fire in the Western United States. As part of this strategy, a science framework for conservation and restoration of the sagebrush biome (Part 1) was recently released (Chambers et al. 2017). The forthcoming Part 2 will focus on management considerations.

Restoration of cheatgrass-dominated landscapes in the sagebrush biome emphasizes resilience to wildfire and resistance to cheatgrass invasion. Research suggests that resilience and resistance are strongly associated with soil moisture and temperature regimes in these semiarid ecosystems (Chambers et al. 2013; Maestas et al. 2016). Management focused on resilience and resistance is critical for local communities that depend on ecosystems services from rangelands such as water for consumption, forage, and recreational opportunities.

Because of the strong feedbacks due to the grass-fire cycle in the Great Basin, Coates et al. (2016) suggested that areas mapped with low resilience and resistance to cheatgrass could be targeted for wildfire suppression efforts to protect vulnerable sage-grouse habitat. The IRFMS used a mid-scale approach to prioritize areas for management and treatment focused on six steps: (1) identifying focal species, resources, or habitats; (2) mapping soil temperature and moisture regimes; (3) development of a decision-support matrix; (4) threat assessment; (5) prioritization; and (6) appropriate management strategies (Chambers et al. 2017).

Integrated approaches such as the IRFMS that consider multiple factors may provide the most likely approach to restore the sagebrush biome. However, many challenges for restoration remain. Davies et al. (2011) noted that research is needed to develop either long-term control or reduction in invasive annual grasses, and that there is a lack of knowledge regarding native seedling establishment ecology and variability (in time and space) to provide opportunities to successfully restore these plant communities (see additional details on restoration in Chap. 8). Despite these hurdles and the significant threats to the sagebrush biome, with sufficient resources, multi-agency cooperation, and use of integrated management approaches, restoration for many sites can be successful. 
2017). Theoretically, invasive plants could generally benefit over natives if they experience reduced negative soil feedbacks or increased positive soil feedbacks relative to natives (Reinhart and Callaway 2006). However, recent studies suggest that invasive plant responses to plant-soil feedbacks may be more idiosyncratic (Suding et al. 2013).

\subsubsection{Invasive Plants and Pollinators}

Insect-based pollination in US wildland and agroecosystems is strongly impacted by invasive species of plants and insects (Box 2.2). Invasive plants directly impact native pollinators (Moroń et al. 2009, in Europe) and indirectly impact native plants via interactions with pollinators. Invasive flowering plants may enhance or reduce pollinator services to native flowering plants by increasing or decreasing pollinator visitation rates or by increasing heterospecific pollen transfer, which is essentially interference competition (Brown et al. 2002; Morales and Traveset 2009). However, in some instances nonnative plants may provide benefits to native pollinators (Goodell 2008; Russo et al. 2016; Stout and Morales 2009; Tepedino et al. 2008). Ironically, removal of invasive legumes during tallgrass prairie restoration may negatively impact pollinator conservation efforts (Harmon-Threatt and Chin 2016). Invasive plants may be relatively successful reproductively in new habitats either because they are either visited by pollinators at similar or greater rates to native plants or because they are self-fertilizing (i.e., autogamous) (Baker 1974; HarmonThreatt et al. 2009; Powell et al. 2011).

Two of the primary managed pollinators in the United States, the western honeybee (Apis mellifera) (Fig. 2.4a) and the alfalfa leafcutter bee (Megachile rotundata), are nonnative insects. The latter is a key pollinator for alfalfa seed production, which forms the basis for hay production for livestock (Pitts-Singer and Cane 2011). Unmanaged invaders
Box 2.2 Interactions Among Invasive and Native Plants and Pollinators in the United States

In the strict sense, the workhorse of pollinators, the western honeybee (Apis mellifera) (Fig. 2.4a), is a managed, nonnative species originating from Western Europe (Franck et al. 1998). The pollination services that it provides in the United States have come under increasing scrutiny as the number of pollination-dependent crops and their planting acreages have grown (Aizen and Harder 2009; Williams et al. 2010) and the general health of the commercial colonies has declined (Cox-Foster et al. 2007; Ellis et al. 2010; vanEngelsdorp et al. 2009). An issue of concern associated with Colony Collapse Disorder is the spread of an invasive natural enemy of the western honeybee, the Varroa mite (Varroa destructor) (Fig. 2.4b), which was introduced into the United States in 1987 (NRC 2007). Originating from Southeast Asia, this invasive pest is parasitic and transmits viruses to the western honeybee (NRC 2007). Another invasive organism originating from Asia is the pathogenic microsporidian Nosema ceranae (not pictured), which also appears to have played a relatively major role in the declining health of the western honeybee in the United States (Chen et al. 2008; Higes et al. 2008; Klee et al. 2007). These are issues of major concern to the U.S. beekeeping industry (vanEngelsdorp and Meixner 2010), which have led to a growing research effort to understand the role of native pollinators (Fig. 2.4d) in wildland and agroecosystems (Artz et al. 2013; Koh et al. 2015).

When invasive plants that do not provide floral resources (e.g., cheatgrass, Fig. 2.4c) replace native flowering plants, native pollinators lose access to pollen and nectar. Conversely, in some instances, invasive flowering plants (e.g., Melilotus spp. and Sonchus spp.) have provided the bulk of pollen collected by managed populations of western honeybees in foraging areas in the Prairie Pothole Region of North Dakota (Smart 2015). Other potential sources of impact on native pollinators are unintentionally introduced species such as the wool carder bee (Anthidium manicatum) (Fig. 2.4e), a solitary bee introduced to North America in the late 1960s from Europe (Gibbs and Sheffield 2009; Miller et al. 2002; Strange et al. 2011; Zavortink and Shanks 2008). The fortuitous management of another accidentally introduced species (from the Near East), the alfalfa leafcutter bee (Megachile rotundata), has had dramatically positive impacts on the production of alfalfa seed in North America (Cane 2003; Pitts-Singer and Cane 2011). However, several other species of invasive megachilid bees in California may negatively impact native bees in the same family by excluding them from suitable nesting cavities (Cane 2003). The intentionally introduced Japanese bee Osmia cornifrons appears to have been accompanied or joined by a Japanese mite, a parasitic wasp, and the look-alike bee $O$. taurus. Throughout the Eastern United States, these two Japanese Osmia are displacing the native bee $O$. lignaria, partly through aggressive competition for nesting sites (Cane 2018). Little is known about interactions between the recently detected Asian giant hornet, Vespa mandarinia Smith, and native plants or pollinators. It is the world's largest hornet and a very aggressive predator that specializes in mass attacking nests of other species and is a major pest in its native range. Thus, it potentially threatens honey bees and native pollinators throughout North America (Matsuura and Yamane 1990, Tripodi and Hardin 2020). 
Fig. 2.4 A nexus of invasive and native plants, pollinators, and pathogens: (a) The western honeybee (Apis mellifera) with a full pollen basket on its hind leg. (Photo by David Cappaert, Bugwood. org); (b-1 and b-2) a western honeybee infected by a phoretic Varroa mite (Varroa destructor). (Photo by Kathy Keatley Garvey, University of California, Davis); (c) Cheatgrass (Bromus tectorum). (Photo by John M. Randall, The Nature Conservancy, Bugwood.org); (d) native bees (Stephen Buchmann, Pollinator Partnership, www.pollinator. org); and (e) the invasive wool carder bee (Anthidium manicatum). (Photo by Kimberly Steinmann, University of California, Bugwood.org)

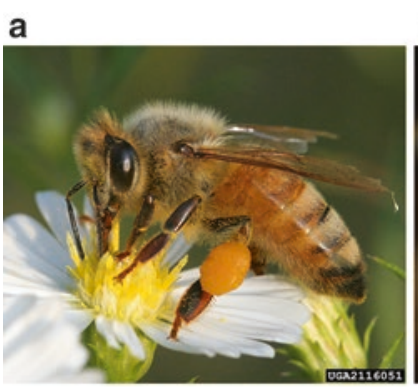

b1 b2
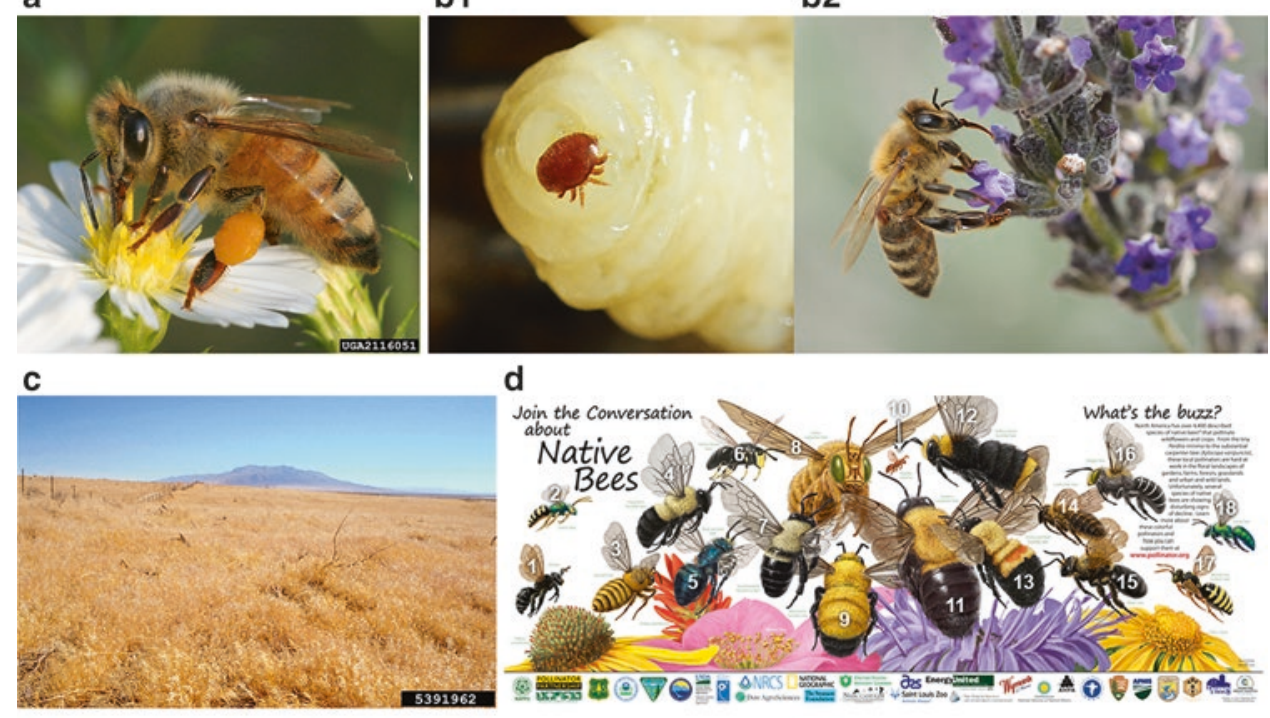

d

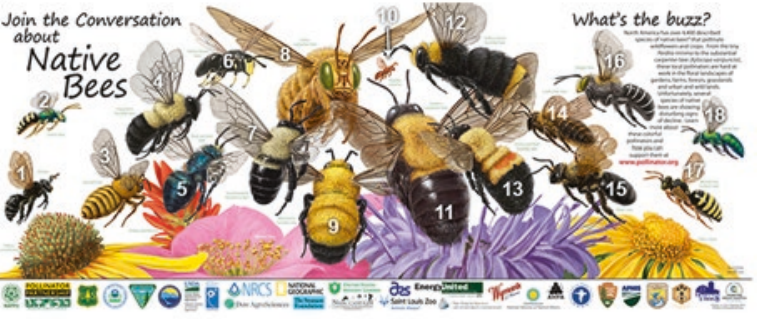

e

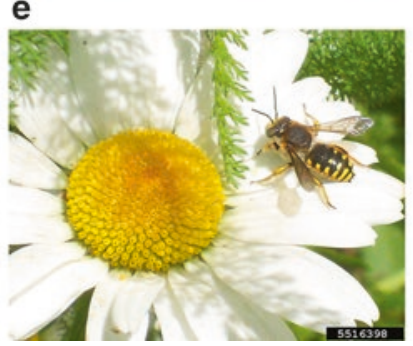

(e.g., the wool carder bee (Anthidium manicatum), Fig. 2.4e) may also impact pollination in various systems. Including these three species, there are at least 25 non-native bees established in the United States and Canada (Cane 2003; NRC 2007), comprising less than $1 \%$ of the continental native bee fauna. Cane (2003) reported that most of the non-native bee species have come from Europe, most nest in stems or wood, and most use many different floral hosts as pollen sources (polylecty). Non-native bees in the United States (NRC 2007) may also impact native pollinators (Cane and Tepedino 2017; Fürst et al. 2014 (in the United Kingdom); Goulson 2003; Stout and Morales 2009) and native plants (Goodell 2008; Goulson 2003; Stout and Morales 2009).

Arguably, the strongest effect of invasive plants on native plant-pollinator interactions may be the large-scale species transformation of plant communities, such as the transition from diverse forb communities to wind-pollinated grasses such as cheatgrass (Fig. 2.4c) or crested wheatgrass (Agropyron cristatum) (Gunnell et al. 2010), across the Great Basin (Mack 1981). Much in the way that invasive grasses have transformed fire regimes over large regions (D'Antonio and Vitousek 1992 (Box 2.1), these wind-pollinated grasses have transformed pollinator systems.

Although there is strong evidence that invasive flowering plants can negatively impact native plants by competing for pollination services (Morales and Traveset 2009), it is unclear how strong these indirect effects are on native plants relative to direct impacts via competition (Brown et al. 2002). In general, the effects of invasive plants on pollinators and pollination services are complex and not fully understood. For example, Russo et al. (2016) demonstrated in Pennsylvania that the invasive spiny plumeless thistle (Carduus acanthoides) was both highly visited and strongly preferred by bees relative to other flowering species. Indeed, greater than four times more Bombus species, a group of native bumblebees recently found to be in decline, were attracted to patches that included the invasive thistle. However, in many cases greater visitation of invasive plants by bees may primarily be about their greater abundance rather than pollinator preference (Williams et al. 2011). Research in California has shown that protein and amino acid compositions of pollen were comparable among invasive and native flowering plants in a plant community visited by bumblebees (Harmon-Threatt and Kremen 2015). Conversely, removal of the invasive shrub Chinese privet (Ligustrum sinense) from the riparian forests of the Southeastern United States dramatically increases the abundance and diversity of pollinator communities, but the potentially intricate mechanisms behind these changes and their relationship to native flora require further study (Hanula and Horn 2011a, b; Hudson et al. 2013). More work is also needed to understand invasive plant effects on pollination, particularly regarding large-scale transitions from forbs to wind-pollinated grasses. 


\subsubsection{Invasive Plant Impacts on Trophic Interactions: A Tangled Web}

Apparent competition, an indirect interaction of two prey species via differential impacts from a shared predator (Holt 1977), is a potential mechanism by which invasive plants impact native plants (Noonburg and Byers 2005). Instances of apparent competition between invasive and native plants are not well demonstrated empirically, but variations on this theme are known. For example, "second-order apparent competition" has been shown to significantly impact native plant recruitment in a weed biocontrol system in which the biocontrol insect is fed upon by a native rodent that also acts as a seed predator on native plants (Pearson and Callaway 2008). "Refuge-mediated apparent competition" (Orrock et al. 2010), wherein an invasive plant provides habitat instead of food to native rodent seed predators, also has been shown to facilitate increased seed predation on native plants (Dangremond et al. 2010; Orrock et al. 2008). Apparent competition and its variations may be an important but understudied means by which invasive plants impact native plants via seed predators and other herbivores.

Invasive plant impacts on native plants can produce negative or positive effects on native animals by altering the quantity or quality of food resources (Lockwood and Burkhalter 2015; Waring et al. 1993), an effect that can transmit indirectly to higher trophic levels (Ortega et al. 2006). Invasive plants can also directly and indirectly affect native animals by altering vegetation architecture (Box 2.3, Fig. 2.5), which can improve or degrade habitat for nesting, hiding, and foraging (Lockwood and Burkhalter 2015). For example, cheatgrass invasion can create such dense stands in the Great Basin relative to native vegetation that it inhibits movement of native rodents (Rodentia) and lizards (Squamata) (Rieder et al. 2010). In contrast, changes in plant architecture have dramatically increased the abundance of native spiders (Araneae) in some grassland systems by altering the quality and quantity of web substrates, which results in indirect negative impacts on spider prey species through both density- and trait-mediated interaction pathways (Pearson 2009, 2010). These examples demonstrate how invasive plants can have either positive or negative direct effects on native animals.

\subsubsection{Invasive Plant Impacts and Evolution}

Plant invasions that shift the structure and function of native communities can alter the evolutionary trajectories of both native and invasive plant species. Plant invaders may adapt to new environments through contemporary evolution, i.e., observable evolutionary change occurring over tens of generations or fewer (Buswell et al. 2011; Carroll et al. 2007) and hybridization (Vellend et al. 2007), and in some cases native plants and animals can adapt to invaders (Lau 2006; Strauss et al. 2006; Vellend et al. 2007). The study of invasions has increased our recognition of contemporary evolution among a wide array of taxa and how evolution of invaders and invaded systems interacts, modifying perceivable impact (Colautti and Lau 2015; Cox 2004; Whitney and Gabler 2008). Examining evolutionary adaptations of invaders suggests that traits associated with impact can differ from those associated with spread, with traits linked to spread being associated more with invasion fronts (Phillips et al. 2010; Sakai et al.
Fig. 2.5 Stand of strawberry guava (Psidium cattleianum) in Glenwood, HI. (Photo courtesy of Jack Jeffrey, taken 2009)

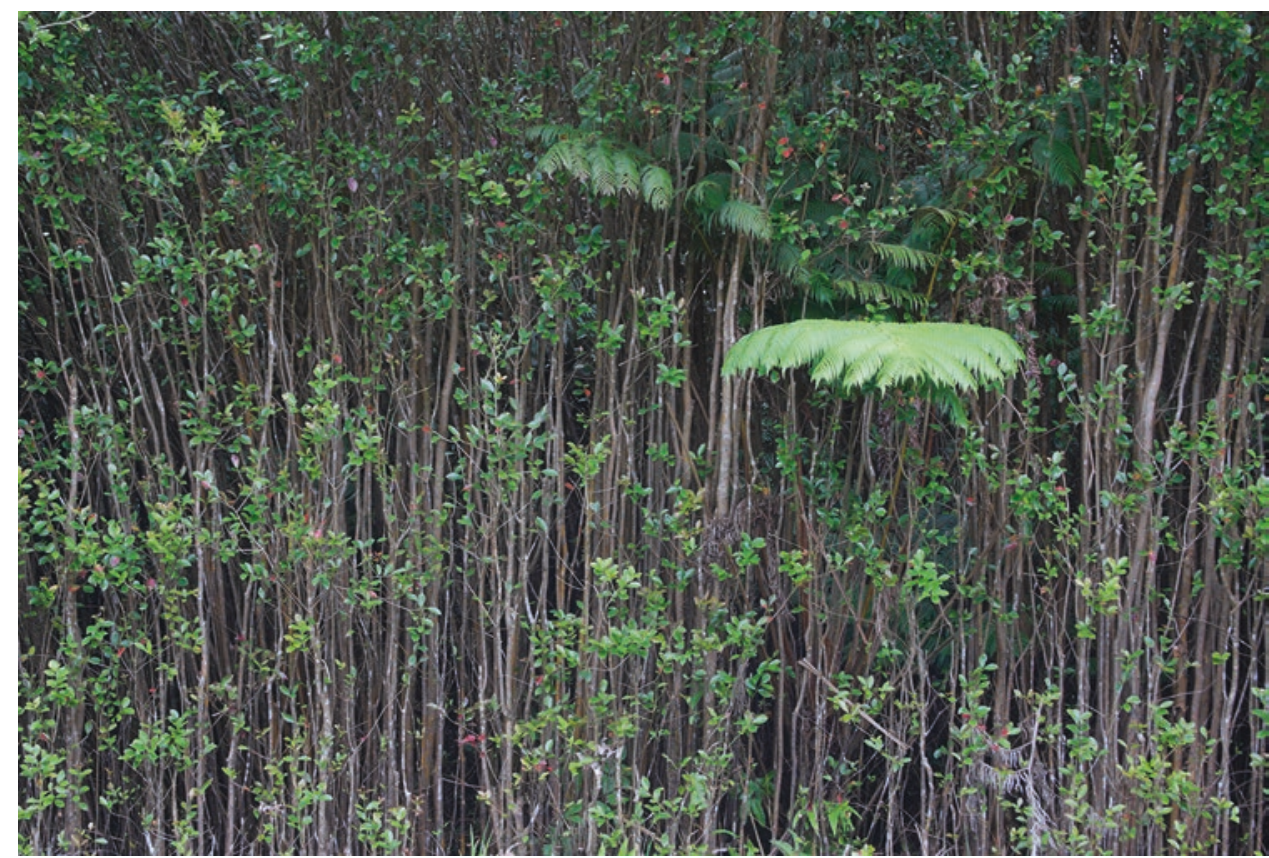




\section{Box 2.3 Strawberry Guava Invasion and Impacts in} Tropical Island Ecosystems

As an ornamental fruit tree, strawberry guava (Psidium cattleianum) has been moved by humans from its native Brazil to new habitats worldwide (Ellshoff et al. 1995). With seeds readily dispersed by birds and pigs, it has become a dominant invader in wet forests of tropical islands (Lorence and Sussman 1986; Space 2013), for example, forming dense thickets and displacing native species across tens of thousands of hectares in Hawaii (Fig. 2.5). In addition to reducing habitat for many endangered species (State of Hawaii 2011), strawberry guava increases water loss from forested watersheds (Takahashi et al. 2011), impedes sustainable native hardwood forestry (Baker et al. 2009), and serves as the primary reservoir host for a major fruit fly pest of agriculture (Vargas et al. 1990). The USDA Forest Service developed a leaf-galling scale insect (Tectococcus ovatus) as a biological control agent, with the intention of substantially reducing vegetative growth and fruit production of strawberry guava (State of Hawaii 2011). This insect was released in Hawaii in 2012, and monitoring is now underway to measure the benefit of biocontrol to agricultural and native forest ecosystems.

2001). Invader plant impacts may also decline over time as the invader and community settle into a new equilibrium such that coexistence with native taxa may occur due to accumulation of natural enemies (Lankau et al. 2009).

\subsubsection{Invasive Plant Impacts: Looking Forward}

Invasive plant impacts vary among communities as a function of differences in the recipient community's susceptibility to invasion (Guo et al. 2015) and environmental context. The biotic resistance hypothesis postulates that higher local species richness increases a community's intrinsic resistance to invasion (Elton 1958). However, research examining this relationship has generated conflicting results depending on spatial scales that are likely linked to underlying resource gradients (Iannone et al. 2015; Stohlgren et al. 2003). This indicates the need to better understand how environmental context interacts with diversity to influence community invasibility and susceptibility to invasive plants impacts. Over large spatial and temporal scales, invasive plant impacts can result in biotic homogenization (a global mixing of highly successful and typically ruderal organisms) and the extirpation or mass extinction of unique, constrained, rare, and/or endemic taxa (McKinney and Lockwood 1999; Olden et al. 2004).

\subsubsection{Key Findings}

- Invasive plants can alter key system processes such as productivity and nutrient cycling, affecting not only native plants but also animals that feed on them.

- There are numerous mechanisms by which terrestrial invasive plants impact native systems, including resource competition, allelopathy, ecosystem engineering, plantsoil feedbacks, effects on pollinators, and apparent competition.

- Competitiveness of invasive plants may be favored when there is increased availability of limiting resources, which in turn may be influenced by natural or human-caused disturbances.

- Invasive plant impacts can result in homogenization of ecosystems and the loss of unique native species.

\subsubsection{Key Information Needs}

- There is a need to better quantify the impacts of multiple invaders on native communities across spatial and temporal scales.

- A better understanding of how resource limitation influences invasive plant impacts on native plants and ecosystems is needed, particularly in relation to human-caused disturbances.

- Conservation of pollinator species is of increasing importance in the management of natural and agricultural systems, and additional research on the degree to which invasive plants affect pollinator populations and networks is needed to inform management strategies.

- Although diverse communities are often thought to be more resistant to plant invasion, a better understanding of how environmental context interacts with diversity to influence community susceptibility to invasive plant impacts is needed (e.g., evaluating the biotic resistance hypothesis).

- Certain mechanisms of invasive plant impact such as allelopathy, plant-soil feedbacks, and apparent competition have received relatively little attention but may be important to understanding effects on ecosystems.

\subsection{Impacts of Invasive Phytophagous Insects and Plant Pathogens in Terrestrial Systems}

Non-native invasive phytophagous (plant-feeding) insects and plant pathogens have impacted forests and other terrestrial systems throughout the United States for nearly 150 years (Liebhold et al. 1995; Niemelä and Mattson 1996). Many of these non-native organisms have had only minor, localized, or regional impacts on forest or shade trees, whereas a small proportion has killed millions of trees (Anagnostakis 1987; Herms and McCullough 2014) (Box 2.4, Fig. 2.6) or pushed 
Fig. 2.6 The emerald ash borer (Agrilus planipennis) and its impact. Adult beetle (a) and larva (b). The adult disperses through flight; the larva damages the phloem (inner bark) of ash (Fraxinus spp.) trees. (Photos courtesy of David Cappaert, Michigan State University, Bugwood. org). Ornamental ash tree killed by emerald ash borer (c). (Photo courtesy of Daniel Herms, The Ohio State University, Bugwood.org). Landscape-level impacts of emerald ash borer (d) (photo courtesy of Troy Kimoto, Canadian Food Inspection Agency, Bugwood.org). Surveying for damage by emerald ash borer (e). (Photo courtesy of Erin Morris, Michigan State University)
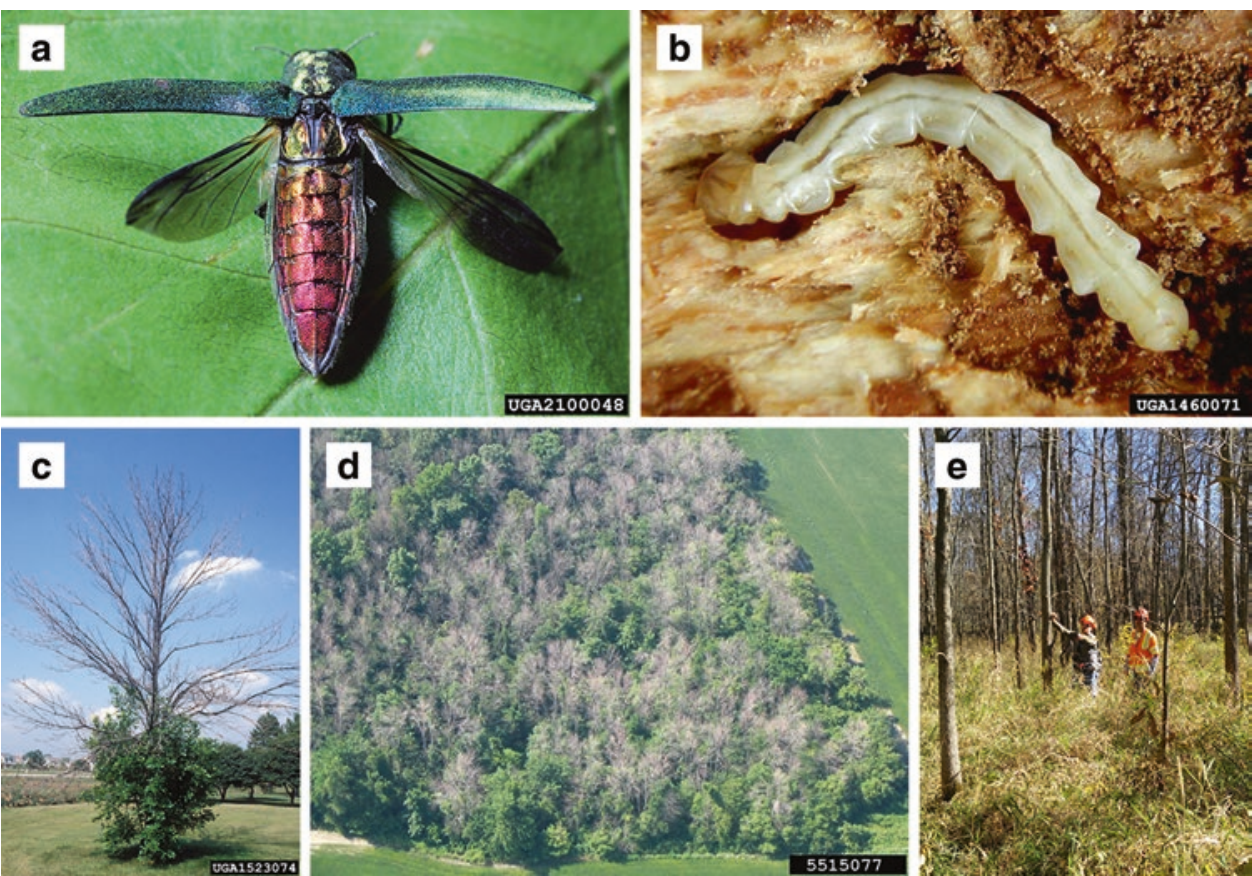

ecologically foundational species toward functional extinction (Ellison et al. 2005). In a recent assessment of more than 450 invasive forest insect species that have established populations in the United States, Aukema et al. (2010) considered 14\% (62 species), plus an additional 16 invasive pathogens, as "high-impact" species, i.e., of regulatory significance or having caused notable damage to forests or urban forest trees. Although these impacts can frequently be attributed primarily to the action of a single invasive organism, a number of important historic and emerging forest diseases are caused by insect-pathogen complexes in which one or more of the organisms are not native to the ecosystem (Houston 1994; Hulcr and Dunn 2011; Sinclair and Campana 1978). In some cases, these complexes of multiple invaders (see Sect. 2.1) provide important examples of how invasive species can function symbiotically to exert strong impact in terrestrial systems. We have highlighted 15 invasive forest insects, pathogens, or insect-pathogen complexes with historic, current, or emerging importance for terrestrial systems in the United States (Table 2.1).

In this subsection, we focus on impacts of invasive insect and pathogen pests of trees not only because of the economic and aesthetic importance of trees to human society but also because trees frequently shape the structure and function of the terrestrial ecosystems in which they occur. Nonetheless, it should be recognized that invasive insects, other invertebrates, and pathogens of other plant or even non-plant hosts cause a variety of impacts in terrestrial systems (e.g., Bohlen et al. 2004; Daszak et al. 2000; Snyder and Evans 2006).

Invasive phytophagous insects and plant pathogens impact forest ecosystems directly by causing damage to, or mortality of, host trees through herbivory or disease development. Structural or physiological damage may result via a number of different mechanistic or phytochemical pathways. For example, high levels of defoliation by larval gypsy moth (Lymantria dispar) reduce carbohydrate allocation to roots and shoots, cause nitrogen $(\mathrm{N})$ deficiency due to reduced $\mathrm{N}$ uptake by roots, and result in growth loss and top dieback (Kosola et al. 2001). Phloem-feeding by larval emerald ash borer (Agrilus planipennis) hinders transport of photosynthates and nutrients, decreases essential foliar amino acids, and culminates in rapid tree mortality (Chen et al. 2011). In addition to depleting carbohydrates, feeding in the vascular system of firs (Abies spp.) and hemlocks (Tsuga spp.) by invasive adelgids (Adelges spp.) induces abnormal xylem formation, reducing water use and producing drought-like symptoms (Domec et al. 2013). Even minor damage associated with feeding or host colonization by certain invasive insects can predispose (e.g., beech scale (Cryptococcus fagisuga)) or inoculate (e.g., redbay ambrosia beetle (Xyleborus glabratus) or smaller European elm bark beetle (Scolytus multistriatus)) trees with virulent pathogens, resulting in host mortality (Houston 1994; Fraedrich et al. 2008). Several damaging forest pathogens extract carbohydrates and cause cankers or necrosis of the cambium (e.g., chestnut blight caused by Cryphonectria parasitica, Anagnostakis 1987), roots (e.g., root disease caused by Phytophthora lateralis, Hansen et al. 2000), or shoots, branches, or stems (e.g., white pine blister rust caused by Cronartium ribicola, Maloy 2001). Other pathogens induce extreme hypersensitive responses in their hosts, such as systemic tyloses triggered by presence of the laurel wilt pathogen (Raffaelea lauricola) in North American Lauraceae (Inch et al. 2012).

Although several authors have proposed empirical models to describe the impact of invasive species (see Sect. 2.1) 
Box 2.4 Profound and Widespread Impact of an Invasive Beetle on Naive Ash Trees in the United States

The emerald ash borer (Agrilus planipennis) is a flatheaded woodborer from Asia that was first discovered in North America in 2002 (Herms and McCullough 2014). Adult beetles in this group are also known as metallic woodborers, as emphasized in this case by the brilliant green color of emerald ash borer adults (Fig. 2.6a). The beetle has spread from the original site of detection in southeastern Michigan (where it was likely established in the early 1990s) to 31 US states (Emerald Ash Borer Information Network 2018) and the Canadian provinces of Manitoba, Ontario, and Quebec as of January 2018 (Canadian Food Inspection Agency 2018; Kimoto 2018). The spread has been described as "stratified," consisting of natural flight dispersal of the adults and longer distance humanassisted spread, largely through infested ash (Fraxinus spp.), firewood, nursery stock, and logs (Herms and McCullough 2014).

The damaging life stage is the larva (Fig. 2.6b), which mines at the phloem-xylem interface of ash trees, eventually causing tree mortality (Fig. 2.6c). Adults feed incidentally on foliage. North American impacts of emerald ash borer have been characterized as ecological, economic, and cultural (Herms and McCullough 2014). Ecological effects include altered understory environment, nutrient cycles, and successional trajectories; facilitation of the spread of lightlimited invasive plants; and increased coarse woody debris. Elimination of ash as a consequence of the feeding activity of larval emerald ash borers threatens nearly 100 species of ash-dependent native invertebrate herbivores (Wagner and Todd 2015). Economically, emerald ash borer is the most destructive and costly forest insect to have invaded the United States (Aukema et al. 2011). The multi-billion dollar cost projections are based largely on removal costs for infested and dead ash trees in communities throughout the Midwest. Cultural impacts are centered on the Native American basket weaving tradition that utilizes black ash (Fraxinus nigra) as the source material (Poland et al. 2015b). The impact of emerald ash borer on ash (Fig. 2.6d) has been monitored in Indiana, Michigan, and Ohio through a series of survey plots (Fig. 2.6e) established in 2002 and 2003 (Marshall et al. 2013; Mercader et al. 2016).

(Lockwood et al. 2007; Parker et al. 1999; Ricciardi 2003), to our knowledge there has been little attempt to apply these quantitative models to predict impacts from specific invasive terrestrial insects or pathogens of trees. Using a more qualitative conceptual framework, Lovett et al. (2006) proposed that the magnitude of short-term (weeks to years) and long-term (decades to centuries) impacts is at least partially a function of three key features of an invasive insect or pathogen-mode of action, host specificity, and virulence-and three key features of its host plant(s) - importance or dominance in the stand, ecological uniqueness, and phytosociology. Noting that these six features vary continuously and independently, Lovett et al. (2006) suggest that exceptionally severe long-term impacts should be expected for a highly virulent, host-specific agent that kills dominant, abundant, and ecologically unique hosts. Although abundance of their primary hosts varies geographically, this scenario is closely representative of impacts caused by hemlock woolly adelgid (Adelges tsugae) (Vose et al. 2013), emerald ash borer (Gandhi and Herms 2010a, 2010b), chestnut blight, and white pine blister rust (Loo 2009). It should be noted that even when host plant species comprise only a very small percentage of the regional biota, impacts may be considered severe in systems where the host is locally abundant. For example, the highly virulent, host-specific pathogen of laurel wilt disease kills nearly all mature stems of native Persea spp. that are substantial canopy components of unique Everglades tree islands, southeastern bayhead swamps, and coastal mixed maritime forests, where their importance to biodiversity and ecological function is high (Hughes et al. 2015; Rodgers et al. 2014; Snyder 2015).

The success of invasive species in their non-native ranges has been viewed traditionally as a function of release from natural enemies, and/or a lack of co-evolved defenses in naive hosts (Elton 1958), frequently resulting in greater negative impacts than that occur in interactions among coevolved species (Paolucci et al. 2013). A number of studies and reviews have evaluated the mixed evidence for the enemy release hypothesis, primarily as it relates to the success of invasive plants (Colautti et al. 2004; Keane and Crawley 2002; Liu and Stiling 2006), but to a much lesser extent for invasive herbivores (Blossey 2011). For invasive insects, evidence for release from enemies has been derived primarily from the successful biological control of several species in natural systems including the European spruce sawfly (Gilpinia hercyniae), larch casebearer (Coleophora laricella), and winter moth (Operophtera brumata) (see Van Driesche et al. 2010; Van Driesche and Reardon 2014; and references therein). Of course, not all invasive insects or pathogens succeed primarily due to enemy release or can be effectively managed via biological control. For example, a robust biological control program is being pursued for the emerald ash borer, and there is recent evidence of released and native parasitoids reducing population growth (Duan et al. 2015). However, North American ash (Fraxinus spp.) 
Table 2.1 Selected high-impact invasive insects, pathogens, or insect-pathogen complexes established in the United States

\begin{tabular}{|c|c|c|c|c|}
\hline \multirow[b]{2}{*}{ Organism } & \multirow[b]{2}{*}{$\begin{array}{l}\text { Disease or } \\
\text { complex name }\end{array}$} & \multicolumn{2}{|l|}{ Impact } & \multirow[b]{2}{*}{ Selected references } \\
\hline & & Hosts & US region & \\
\hline \multicolumn{5}{|l|}{ Insects } \\
\hline $\begin{array}{l}\text { Agrilus planipennis } \\
\text { (emerald ash borer) }\end{array}$ & N/A & Ash & $\begin{array}{l}\text { Eastern and } \\
\text { western }\end{array}$ & Herms and McCullough (2014) \\
\hline $\begin{array}{l}\text { Anoplophora glabripennis } \\
\text { (Asian longhorned beetle) }\end{array}$ & N/A & $\begin{array}{l}\text { Maple, poplar, } \\
\text { willow, other }\end{array}$ & Eastern & Dodds and Orwig (2011) and Hu et al. (2009) \\
\hline $\begin{array}{l}\text { Adelges tsugae } \\
\text { (hemlock woolly adelgid) }\end{array}$ & N/A & Hemlock & Eastern & Havill et al. (2014) and Vose et al. (2013) \\
\hline $\begin{array}{l}\text { Adelges piceae } \\
\text { (balsam woolly adelgid) }\end{array}$ & N/A & Fir & $\begin{array}{l}\text { Eastern and } \\
\text { western }\end{array}$ & $\begin{array}{l}\text { Smith and Nicholas (1998) and Davis et al. } \\
(2020)\end{array}$ \\
\hline $\begin{array}{l}\text { Lymantria dispar } \\
\text { (gypsy moth) }\end{array}$ & N/A & $\begin{array}{l}\text { Oak, numerous } \\
\text { other }\end{array}$ & Eastern & Davidson et al. (2001) \\
\hline \multicolumn{5}{|l|}{ Pathogens } \\
\hline Cryphonectria parasitica & Chestnut blight & Chestnut & Eastern & Anagnostakis (1987) \\
\hline Phytophthora ramorum & $\begin{array}{l}\text { Sudden oak } \\
\text { death }\end{array}$ & Oak, tanoak & Western & $\begin{array}{l}\text { Grünwald et al. }(2008,2012) \text { and Rizzo et al. } \\
(2002)\end{array}$ \\
\hline Cronartium ribicola & $\begin{array}{l}\text { White pine } \\
\text { blister rust }\end{array}$ & Five-needle pines & $\begin{array}{l}\text { Eastern and } \\
\text { western }\end{array}$ & Maloy (2001) \\
\hline Phytophthora lateralis & $\begin{array}{l}\text { Port-Orford- } \\
\text { cedar root } \\
\text { disease }\end{array}$ & Port-Orford cedar & Western & Jules et al. (2002) \\
\hline $\begin{array}{l}\text { Sirococcus } \\
\text { clavigignenti-juglandacearum }\end{array}$ & Butternut canker & Butternut & Eastern & Broders et al. (2015) \\
\hline \multicolumn{5}{|l|}{ Insect-pathogen complexes } \\
\hline $\begin{array}{l}\text { Insect: Cryptococcus fagisuga } \\
\text { (beech scale) } \\
\text { Pathogens: Nectria coccinea } \\
\text { var. faginata, Nectria galligena }\end{array}$ & $\begin{array}{l}\text { Beech bark } \\
\text { disease }\end{array}$ & Beech & Eastern & Houston (1994) \\
\hline $\begin{array}{l}\text { Insects: Scolytus multistriatus } \\
\text { (smaller European elm bark } \\
\text { beetle), } \\
\text { Scolytus schevyrewi } \\
\text { (banded elm bark beetle), } \\
\text { Hylurgopinus rufipes } \\
\text { (native elm bark beetle) } \\
\text { Pathogens: Ophiostoma ulmi, } \\
\text { Ophiostoma novo-ulmi }\end{array}$ & $\begin{array}{l}\text { Dutch elm } \\
\text { disease }\end{array}$ & Elm & $\begin{array}{l}\text { Eastern and } \\
\text { western }\end{array}$ & $\begin{array}{l}\text { Brasier and Buck (2001), Jacobi et al. (2007, } \\
\text { 2013), Negrón et al. (2005), and Sinclair and } \\
\text { Campana (1978) }\end{array}$ \\
\hline $\begin{array}{l}\text { Insect: Xyleborus glabratus } \\
\text { (redbay ambrosia beetle) } \\
\text { Pathogen: Raffealea lauricola }\end{array}$ & Laurel wilt & $\begin{array}{l}\text { Redbay, } \\
\text { sassafras, others }\end{array}$ & Eastern & Fraedrich et al. (2008) and Hughes et al. (2015) \\
\hline $\begin{array}{l}\text { Insect: Pityophthorus juglandis } \\
\text { Pathogen: Geosmithia morbida }\end{array}$ & $\begin{array}{l}\text { Thousand } \\
\text { cankers disease }\end{array}$ & $\begin{array}{l}\text { Walnut, } \\
\text { butternut, wingnut }\end{array}$ & $\begin{array}{l}\text { Eastern and } \\
\text { western }\end{array}$ & Seybold et al. (2016) and Tisserat et al. (2009) \\
\hline $\begin{array}{l}\text { Insect: Euwallacea spp. } \\
\text { (polyphagous shot hole borer) } \\
\text { Pathogens: Fusarium spp., } \\
\text { Acremonium spp., Graphium } \\
\text { spp. }\end{array}$ & Fusarium wilt & $\begin{array}{l}\text { Alder, boxelder, } \\
\text { cottonwood, } \\
\text { sycamore, } \\
\text { willow, others }\end{array}$ & $\begin{array}{l}\text { Western } \\
\text { (California) }\end{array}$ & $\begin{array}{l}\text { Eskalen et al. (2013), Lynch et al. (2016), and } \\
\text { Umeda et al. (2016) }\end{array}$ \\
\hline
\end{tabular}

planted in the native range of emerald ash borer in Asia (i.e., ostensibly with the full complement of native natural enemies) are heavily attacked and killed (Liu et al. 2003), suggesting that top-down pressure by natural enemies alone does not preclude substantial impact. With invasive insects, in addition to release from natural enemies as an explanation for invasion success, there is the potential for non-native insects to utilize a niche marked by "pheromone-free space" from native insects in the same guild or feeding group. This concept, based on a reduction in competition from reduced overlap of behavioral chemical "channels" of communication, is being explored with roundheaded woodborers (also known as longhorned beetles) (Millar and Hanks 2017; Mitchell et al. 2015).

Lack of co-evolutionary history may result in defensive mismatches between native plants and their invasive herbivores or pathogens, such as when elicitor-receptor-based defenses are not recognized or only weakly induced in a 
plant upon attack, or when toxin-based constitutive defenses have not been selected naturally for the specific invader (Desurmont et al. 2011; Verhoeven et al. 2009). A growing body of research on ash indicates that differences in both constitutive and induced defenses (especially in phloem chemistry) confer resistance of Asian ash species to the emerald ash borer relative to susceptible North American congeners (Poland et al. 2015a). Evidence for greater susceptibility or vulnerability of naive host plants compared with co-evolved hosts has been presented for numerous other invasive forest insects and pathogens including the hemlock woolly adelgid (Havill et al. 2011; Montgomery et al. 2009), viburnum leaf beetle (Pyrrhalta viburni) (Desurmont et al. 2011), the thousand cankers disease vector Pityophthorus juglandis (Hefty et al. 2018), pathogen Geosmithia morbida (Utley et al. 2013), the laurel wilt disease pathogen R. lauricola (Fraedrich et al. 2015), and the sudden oak death pathogen Phytophthora ramorum (Rizzo et al. 2005). The escape of pathogens from their usual selection pressures when introduced into new environments and onto new hosts can provide opportunities for rapid evolution and hybridization that may also influence the magnitude of their impact (Brasier 2001; Hansen 2008; Parker and Gilbert 2004).

In the last decade, a number of authors have reviewed the varied, interacting, and sometimes cascading ecological effects of outbreaks of invasive insects and/or pathogens in forests or other natural systems (Gandhi and Herms 2010a; Kenis et al. 2009; Loo 2009; Lovett et al. 2006; Moser et al. 2009). Tree mortality caused by invasive insects or pathogens thins or creates gaps in the forest canopy to varying degrees depending on key characteristics of invader and host summarized above (Lovett et al. 2006) (Box 2.5, Fig. 2.7). Over the short term, this canopy thinning can reduce host species' stem density and basal area; alter understory microenvironmental factors such as light availability, temperature, and moisture regimes; and increase organic inputs to the forest floor in the form of downed coarse woody debris, leaf fragments, frass (insect excrement and feeding debris), or insect biomass (Cobb et al. 2012; Gandhi and Herms 2010a; Vose et al. 2013). These changes in turn can alter hydrologic and biogeochemical cycling regimes (see Chap. 3) (Brantley et al. 2013, 2015; Clark et al. 2010; Lovett et al. 2010); the establishment, relative abundance, and growth of native and non-native understory plants; and the overall species composition and structure of the plant community (Gandhi and Herms 2010a; Morin and Liebhold 2015). Associated impacts on terrestrial and aquatic fauna may occur due to short- or long-term shifts in the availability and quality of food (including the invasive organism itself) (Barber et al. 2008; Koenig et al. 2011, 2013), host plants (Chupp and Battaglia 2014; Gandhi and Herms 2010b; Wagner 2007), habitat (Rabenold et al. 1998; Tingley et al. 2002), com-

\section{Box 2.5 Responding to Sudden Oak Death Through} Collaborative Management

Sudden oak death (SOD) caused by the invasive pathogen Phytophthora ramorum threatens oak woodlands, urban forests, and horticultural industries. Currently, the disease is established and regulated in forests in California and Oregon. Because numerous eastern oak species and certain associated understory forest plants have shown susceptibility to this disease, there is a potential risk to oak forests beyond the regulated areas. Once established, SOD may continue to have significant negative impact beyond the known infestations, since the loss of oak would adversely affect ecosystem functions such as water quality, biodiversity, and forest structure.

The USDA Forest Service has responsibility in developing, implementing, and promoting innovative management strategies in response to threats to the nation's forests. Likewise, USDA Animal and Plant Health Inspection Service (APHIS) has the lead regulatory role to prevent further spread of damaging agents and protect natural resources. State forestry and agriculture agencies have corresponding roles within their respective States, especially the State Plant Regulatory Official (SPRO), who must determine the extent of any regulatory action needed once SOD has been positively confirmed. It is clear that once established in a forest, complete removal of $P$. ramorum has a low likelihood of success given the broad host range of the pathogen, available pathways for spread, and complex biological life history. It takes continued diligence, collaboration, and constant monitoring, especially given many invasive species have long lag periods prior to fully expressing their disease potential. Collaborative management in practice has many challenges, but with lessons learned in California and Oregon, it may be possible to successfully mitigate the negative impacts of $P$. ramorum. To this end, the USDA agencies and their partners continue to address the ongoing threat of SOD.

petitors (Work and McCullough 2000), or natural enemies (Gandhi and Herms 2010a; Redman and Scriber 2000). These impacts are particularly pronounced when the host plant of the invasive insect or pathogen is a "foundation species" that defines the structure of the community and has a stabilizing effect on ecosystem processes (Ellison et al. 2005).

From the perspective of human populations, the impact of invasive insects and pathogens on species, communities, and ecosystems is most acutely experienced via changes in the 
Fig. 2.7 Tree mortality caused by sudden oak death in (a) Southern Oregon. (Photo courtesy of Bruce Moltzan, USDA Forest Service, Washington Office) and (b) Monterey County, CA. (Photo courtesy of Tom Coleman, USDA Forest Service, suddenoakdeath.org)
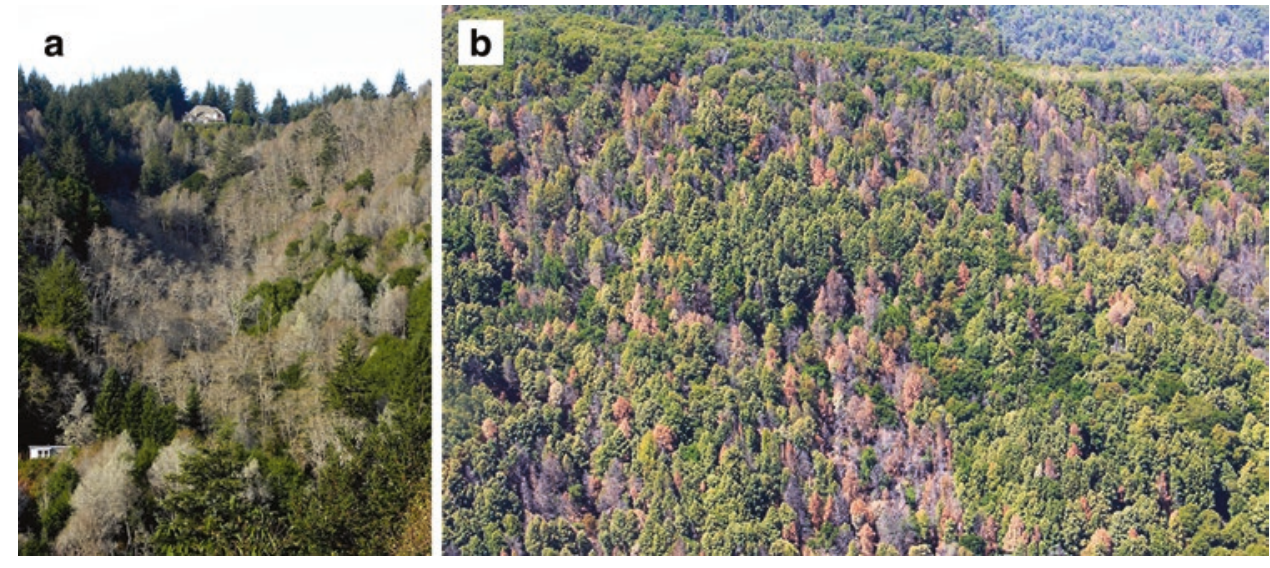

services the affected urban and wildland ecosystems provide to human welfare. Ecological impacts of major forest pests naturally translate into effects on various types of services, i.e., provisioning (e.g., timber and non-timber products); regulating (e.g., air and water quality/quantity, climate regulation); and cultural (e.g., recreation, aesthetics, shade) services (Charles and Dukes 2008; Pejchar and Mooney 2009). However, relatively few studies have quantified impacts on these services by invasive forest insects and pathogens (Holmes et al. 2009). Efforts to quantify direct costs associated with timber losses (Houston 1994), tree removals and replacements (Kovacs et al. 2010; Sydnor et al. 2007), and reduced property values (Holmes et al. 2005) have been made for major invasive pests such as the emerald ash borer, beech scale, and hemlock woolly adelgid, but assessments of direct economic impacts for many other invasive pests are lacking, and studies of indirect or non-market impacts are largely absent. Aukema et al. (2011) conservatively estimated an economic cost of nearly $\$ 5$ billion per year on governments, landowners, and households due to timber losses, reduced property values, and other expenditures associated with invasive forest insect infestations in the United States, but did not include impacts to non-market ecosystem services due to the scarcity of available data. Useful impact metrics for non-market values and ecosystem services may better inform policy decisions that could help mitigate against the negative effects of invasive insect and pathogen introduction, establishment, and spread (Boyd et al. 2013; Chornesky et al. 2005).

\subsubsection{Key Findings}

- Invasive plant-feeding insects and plant pathogens (or combinations of both) have large ecological impacts in forests. As they kill the dominant trees, they alter the sunlight, temperature, water and nutrient cycles, and plant composition of the forest, causing potential shifts in animal communities as well.

- Tree mortality caused by invasive insects and pathogens leads to enormously high costs of tree removal, other management responses, and reduced property values in urban and residential landscapes.

- The severity of impact caused by invasive insects or pathogens is at least partially a function of key traits of the invader (e.g., mode of action, host specificity, and virulence), as well as key characteristics of its host plant(s) (e.g., dominance, uniqueness, phytosociology).

- Impacts are particularly large when the affected native organism is a "foundation species" that defines and stabilizes ecosystem processes.

- Factors influencing the success of invasive insects and pathogens include their release from natural enemies, "pheromone-free space," defensive mismatches between plants and invaders, and/or rapid change when released from usual selection pressures.

\subsubsection{Key Information Needs}

- Models for characterizing the impact of invasive insects and pathogens have been mostly qualitative, and application of more quantitative approaches could help improve impact predictions and allow for better comparisons among invaders.

- In order to adequately assess the potential value of biological control strategies, more experimental research is needed to determine the degree to which release from natural enemies contributes to the success of specific invasive herbivores (e.g., evaluating the enemy release hypothesis).

- Accurate assessments of both economic and non-market impacts are needed for most invasive insects and pathogens, including development of impact metrics for eco- 
system values and services that can be used to better inform policy and management decisions.

\subsection{Impacts of Invasive Vertebrates in Terrestrial Systems}

Invasive terrestrial vertebrates (i.e., amphibians, reptiles, birds, and mammals) in the United States include species that have been relatively recently introduced (since European colonization of North America) and species that persist due to close association with human habitation (i.e., peridomestics), such as several rat and avian species. Invasive vertebrates are estimated to cause more than $\$ 46$ billion in damage and control costs in the United States annually, including more than $\$ 37$ billion for control and damage from mammals, $\$ 1.9$ billion for birds, and $\$ 5.6$ million for reptiles (Pimentel 2011; Pimentel et al. 2000). This is a conservative estimate in that it accounts for only a subset of all 81 mammal, 99 bird, 69 reptile, and 11 amphibian species that could potentially be considered (Fall et al. 2011). Additionally, the estimates do not consider all costs. For example, damage estimates for feral swine (Sus scrofa) (\$1.5 billion U.S.) (Pimentel 2011) include only crop damage and control costs, but not damage to other property such as landscaping and vehicles (via collision) or to native plant and animal species, soil, or water. Traditionally excluded from discussions of invasive terrestrial vertebrates are a group of species that have become naturalized and culturally accepted, such as feral horses (Equs caballus). In this section, we will also exclude species undergoing natural range expansion into previously unoccupied areas, even when facilitated by a human modified landscape, such as coyotes (Canis latrans) spreading to the Eastern United States. Here we cover economic and ecological impacts of vertebrates that alter the biological and physical composition, structure, or function of native populations, communities, or ecosystems in ways that decrease the ecosystem services or have other undesired ecological effects (Ricciardi et al. 2013) while also noting some examples of positive effects on particular species.

Native flora are often affected directly by the actions of invasive vertebrate grazers such as goats (Caprinae), rabbits (Leporidae), and horses and burros (Equidae). In Olympic National Park in Washington State, mountain goats (Oreamnos spp.) were introduced in the 1920s (Houston and Schreiner 1995) and are known to impact vegetation near rocky outcrops, as goats preferentially graze on alpine plants such as Idaho fescue (Festuca idahoensis) and showy sedge (Carex spectabilis) (Pfitsch and Bliss 1985). They also damage other native vegetation through the creation of dirt wallows (Pfitsch and Bliss 1985). Similarly, wild burros (Equus africanus asinus) impacted sensitive vegetation through grazing in Grand Canyon National Park in Arizona and were ultimately removed (Houston and Schreiner 1995). Removal of grazers is often a management goal, but ecosystems are complex and removal of grazers can lead to novel issues. For example, on Santa Cruz Island in California, the removal of introduced grazers created an increase in the abundance of invasive weeds (Myers et al. 2000).

Direct agricultural costs are associated with invasive wildlife. Starlings (Sturnus vulgaris) occur at high densities in agricultural areas and are estimated to cause more than $\$ 800$ million in damage by eating grain (Pimentel et al. 2000). Sixty individual starlings were introduced in the United States in 1890 when an attempt was made to bring in every bird species described in the plays of William Shakespeare. This frivolous action has led to a population explosion, where today starling numbers are greater than 150 million individuals and span the entire continent (Homan et al. 2017). Similarly, domestic hogs (Sus scrofa) were introduced into mainland North America in the sixteenth century by Spanish explorers and later by settlers looking to have a constant and familiar food supply. The native range of Eurasian wild boar (also Sus scrofa, from which domestic hogs are derived) is North Africa and Eurasia, but feral swine (including feral hogs, wild boar, and admixtures of the two) have expanded in North America to at least 38 states (Bevins et al. 2014). Massive agricultural damage (Jay et al. 2007; McClure et al. 2015) and contamination of agricultural crops and potable water with $E$. coli and other disease pathogens (Jay et al. 2007; Kaller and Kelso 2006) have accompanied this population and range expansion.

Invasive terrestrial vertebrates can also directly impact native fauna. Invasive black rats (Rattus rattus) are voracious nest predators on many Hawaiian bird species, including the 'Elepaio (Chasiempis species complex), monarch flycatchers rated as "vulnerable" by the International Union for the Conservation of Nature (Amarasekare 1993; Loope et al. 1988; Vanderwerf and Smith 2002). On O'ahu, after rat control was instituted via snap traps and poison baits, researchers noted a $112 \%$ increase in 'Elepaio reproduction; a $66 \%$ increase in survival of female 'Elepaio; restoration of site fidelity, female age structure, and female recruitment; and an increase in the population growth rate (Vanderwerf and Smith 2002). Globally, island ecosystems, especially the avifauna, have been strongly impacted by invasive terrestrial vertebrates (Harper and Bunbury 2015; Jones et al. 2008, 2016).

Although most direct effects of invasive vertebrate species on native flora and fauna are detrimental to the native populations, there are cases where invasive species improve conditions for native populations (Rodriguez 2006). Invasive vertebrates can act as a food subsidy to native predator populations. In the United Kingdom, invasive rabbits (Oryctolagus cuniculus) have increased populations of European wild cats (Felis silvestris), polecats (Mustela putorius), red kites (Milvus milvus), and common buzzards (Buteo buteo) (Lees 
and Bell 2008). In the United States, there is evidence that invasive terrestrial vertebrates can make up substantial portions of the diet of native carnivores, including endangered species. For example, the dominant prey item in the diet of the Florida panther (Puma concolor) is feral swine ( $42 \%$ of scats contained this species) (Maehr et al. 1990).

Terrestrial invasive species can have direct impacts not only on other species but on the geomorphology of the landscape itself. These "ecosystem engineers" (Jones et al. 1996) can change the ecology of an entire system by disrupting the hydrology or changing the vegetative community. One terrestrial invasive vertebrate species acting as an ecosystem engineer in the United States is nutria (Myocastor coypus), a semiaquatic rodent native to South America. The species was introduced at the end of the nineteenth century into California and later into the Southeastern United States for fur farming (Evans 1970). Nutria are known as major consumers of vegetation and can completely denude an area surrounding a waterbody (Fall et al. 2011). They have aquatic and terrestrial dispersal capabilities and are spreading throughout the United States (Guichón and Cassini 1999). Nutria can change the course of a waterway and are blamed for turning vegetated marshes into open water ponds, impacting natural tidal flood controls (Swank and Petrides 1954). Nutria also use a burrow for rearing young, which has been shown to weaken levees and other irrigation structures. They are also major crop pests in the Southeastern United States where they damage rice, sugarcane, cereal, grain, beets, peanuts, melons, and alfalfa (Fall et al. 2011). Overall, the species has the ability through its burrowing and food habits to morphologically change an area, which in turn impacts entire aquatic communities.

Invasive feral swine are also ecosystem engineers. The damage they cause is due to their digging, rooting, and plowing activities, which damage crops, lead to soil erosion, and have been shown to disrupt wetland ecosystems (Engeman et al. 2007; Fall et al. 2011). This damage is greatest in wet environments but can also impact terrestrial wildlands and agricultural areas. From an ecological perspective, feral swine rooting has been shown to influence plant succession and species composition, which in turn has trophic effects on other species that utilize those plant communities (Campbell and Long 2009; Engeman et al. 2007). Feral swine also depredate many native vertebrates including birds, reptiles, and, reportedly, domestic livestock (Seward et al. 2004).

Ecosystem engineers are a type of keystone species, which is a species whose impact is large relative to its proportional biomass in the community (Mills et al. 1993). Burmese pythons (Python bivittatus) in the Florida Everglades could be considered a keystone invasive terrestrial vertebrate. Burmese pythons were imported to the United States from Southeast Asia through the pet trade and now are a top predator in the Everglades, where they were first sighted in the 1980s. They have spread throughout southern Florida including all of Everglades National Park (Dorcas et al. 2011). Road surveys from 2002 to 2011 have documented declines in sightings of native vertebrates: raccoons (Procyon lotor) (99.3\%), opossum (Didelphis virginiana) $(98.9 \%)$, bobcats (Lynx rufus) $(87.5 \%)$, and rabbits (Sylvilagus spp.) (100\%) (Dorcas et al. 2012). All of these species are prey of Burmese pythons.

Indirect effects of an invasive vertebrate species on native populations can take several forms, including negative impacts on the health of humans and native fauna. Invasive vertebrates can harbor pathogens that cause disease, act as new vectors for disease pathways, reduce crop yield or harm livestock that in turn leads to increased human disease, and contaminate potable water (Davis 2009; Fall et al. 2011; Hall et al. 2008; Meng et al. 2009). A simple example is the ability of feral swine to spread diseases such as brucellosis, leptospirosis, influenza, and pseudorabies, which impact humans either through direct pathogen transmission or through indirect transmission through livestock (Hall et al. 2008; Witmer et al. 2003). In a review of emerging infectious diseases in humans, Jones et al. (2008) found that $60.3 \%$ were zoonoses, with $71.8 \%$ originating in wildlife; it is not surprising that introductions of terrestrial vertebrates are linked to increases in human disease. Similarly, non-native arctic fox (Alopex lagopus) on the Pribilof Islands, a critical northern fur seal (Callorhinus ursinus) breeding ground, may be responsible for the spread of Salmonella enteritidis in seals, as foxes are often seen feeding on placentae and dead pups and are a known reservoir of this disease in other locations (Stroud and Roelke 1980).

Invasive vertebrates can compete with native fauna for resources. Feral swine consume oak (Quercus spp.) and hickory (Carya spp.) mast, thereby competing directly with native wildlife for this important food source (Elston and Hewitt 2010; Henry and Conley 1972). Competition can also be for the same resource used in different ways. For example, nonnative grazers, such as European rabbits (O. cuniculus) or goats (Capra hircus), can reduce the abundance and distribution of native vegetation, which may be used by other species for cover and food. Between 1903 and 1923, rabbit grazing was responsible for the local extinction of 26 species of plants on Laysan in Hawaii (Atkinson 1989; Courchamp et al. 1999). Transformation of this native ecosystem by rabbits has been blamed for the loss of several species of land birds on Laysan and the reduction of several reptile populations (Atkinson 1989). These indirect effects can also impact multiple trophic levels. On islands where there are both non-native domestic cats and rats, rats can serve as an important overwinter food source for cats, which in turn affect predation rates of native birds (Courchamp et al. 1999; Zavaleta et al. 2001).

Trophic level effects can be difficult to demonstrate as the strength of interaction can attenuate throughout a food web or chain; alternatively, a trophic cascade can occur if a top 
predator's abundance changes, thereby altering prey density, which releases the lower trophic level. Some of the best trophic interaction studies have been conducted on oceanic islands. Pigs were introduced to California's Channel Islands, became feral, and rapidly increased in abundance. Golden eagles (Aquila chrysaetos) were drawn to the islands and ultimately colonized due to the constant food subsidy of the feral pigs. Golden eagles then began preying on native Channel Island foxes (Urocyon littoralis), whose numbers declined precipitously, which released the competitively inferior native spotted skunk (Spilogale gracilis amphiala), whose numbers boomed (Roemer et al. 2002). Similarly, Croll et al. (2005) show that released foxes on the Aleutian Islands severely reduce seabird numbers (see below), which then ultimately impacted nutrient transport from the ocean to the land. The change in nutrient transport influenced soil fertility and changed native grasslands to forb- and shrubdominated ecosystems (Croll et al. 2005). These oceanic island studies consistently show that a terrestrial invasive apex predator can affect food webs in complex ways involving top-down forcing and bottom-up nutrient exchanges (Maron et al. 2006).

A plethora of indirect economic costs are associated with managing invasive terrestrial vertebrate species. Costs of removing predators such as arctic fox, cats (Felis catus), and rats (Rattus spp.) on islands are substantial, but necessary to protect threatened seabirds (Ebbert and Byrd 2002). Foxes were first brought to the Aleutian Islands in the mid-1700s, and a fox farming boom continued there through the early part of the 1900s. However, escaped foxes that established invasive populations caused much ecological damage to seabird colonies requiring active management remediation. Removal of foxes on 39 islands, while expensive, was immediately successful with a fivefold increase in nesting birds in 10 years (Ebbert and Byrd 2002). The native Aleutian goose (Branta hutchinsii leucopareia) population in the Aleutian Islands went from 1000 birds in 1975 to over 35,000 by 2000 once invasive mammal predators were removed. Similarly, restoration by the removal of wild pigs has been necessary for the recovery of native mammals on California's Channel Islands (Roemer et al. 2002). Likewise, in Hawaii, almost all of the native birds are threatened by invasive rodents and other mammalian predators (Amarasekare 1993; Hammond et al. 2015; Harper and Bunbury 2015). In addition to eradication costs are the costs of threatened species recovery (e.g., captive breeding programs) for those endemic Hawaiian birds impacted by invasive predators.

\subsubsection{Key Findings}

- Invasive terrestrial vertebrates cause impacts to native systems through a wide variety of mechanisms, including overgrazing, seed consumption, predation and related indirect trophic effects, resource competition, and hybridization with native species.

- Invasive vertebrates (e.g., feral swine or nutria) that act as ecosystem engineers through rooting, burrowing, or altering hydrologic patterns can cause substantial ecological and economic impacts.

- Invasive vertebrates can also introduce or serve as vectors of harmful pathogens that cause disease in wildlife, livestock, and humans.

- Economic impacts associated with invasive vertebrates include not only damage to crops and ecosystems but costs of their control or eradication and the cost of recovering or conserving native species threatened by the invasion.

\subsubsection{Key Information Needs}

- Economic impacts of invasive vertebrates are likely underestimated, and better accounting of the full costs associated with damage to native flora and fauna, soil, water, property, and human health are needed, in addition to costs associated with crop damage and control efforts.

- Effects of introducing invasive vertebrates can attenuate through food chains when the species functions as either prey or predator, resulting in numerous direct or indirect interactions. Additional research should focus on identifying and quantifying complex impacts that cascade across trophic levels.

\subsection{Impacts of Invasive Plants in Aquatic Systems}

Invasive plants are found throughout the United States across a wide variety of aquatic habitats, including lakes, ponds, rivers, streams, estuaries, and wetlands. Species of concern represent diverse taxonomic groups and include not only angiosperms (monocotyledonous and dicotyledonous flowering plants) but also macroalgae with plant-like growth forms. There are three main growth forms of aquatic invasive plants: floating (on the water's surface), submersed (rooted underwater but potentially topping out to form surface mats), and emergent (erect stems above or on the surface of the water/saturated soils).

Regardless of growth form, aquatic invasive plants can have severe effects, altering environmental conditions, ecosystem processes, plant and animal communities, and human uses of water bodies. Freshwater aquatic habitats appear to be disproportionately vulnerable to and negatively affected by invasive species compared to terrestrial habitats (Moorhouse and Macdonald 2015). This is because of both the wide range of vectors available for spread of live organisms, such as 
boats, ballast water, and the aquarium trade, and the susceptibility of aquatic systems to hydrologic, nutrient, and other disturbances (Lodge et al. 1998; Zedler and Kercher 2004). Aquatic invasive plants are not only "drivers" of change that directly alter habitats but also "passengers" of change that have become more abundant in response to anthropogenic stressors and disturbances (sensu MacDougall and Turkington 2005). The extent to which invasive plants impair aquatic habitats, and to which they can be effectively controlled, depends on a variety of factors, including site conditions, detection and response times, and management decisions.

As invasive plants become more abundant in an aquatic habitat, their potential impacts on environmental conditions increase. These environmental changes can then have cascading effects on biodiversity, ecosystem functioning, and human uses. A fundamental attribute altered by invasive plants is light availability, particularly when canopyproducing floating (e.g., water hyacinth (Eichhornia crassipes)) or submersed species (e.g., hydrilla (Hydrilla verticillata) and Eurasian watermilfoil (Myriophyllum spicatum)) reduce underwater penetration of sunlight (Smith and Barko 1990; Villamagna and Murphy 2010) or tall emergent species (e.g., non-native common reed (Phragmites australis haplotype M) and hybrid cattail (Typha $\times$ glauca) overtop shorter native plants (Larkin et al. 2012a). Aquatic invasive plants can also alter microclimates, for example, reducing water and substrate temperatures and variability (Larkin et al. 2012a; Schmitz et al. 1993), and water chemistry parameters (e.g., pH, redox potential, and nutrient concentrations) (Carpenter and Lodge 1986; Hummel and Kiviat 2004; Posey et al. 1993). Dissolved oxygen is of particular concern, as it can become depleted when high biomass of senesced invasive plants undergoes microbial decomposition or at night or during prolonged cloud cover when oxygenproducing photosynthesis gives way to oxygen-consuming respiration in large mats of vegetation (Caraco and Cole 2002; Pennington 2014; Sousa 2011).

Changes to key ecosystem processes accompany these shifts in environmental conditions. For example, primary productivity often increases with aquatic plant invasions (Nichols and Shaw 1986; Zedler and Kercher 2004). Movement of water may be disrupted by dense growth of non-native vegetation and sediment can be trapped at higher rates (Petticrew and Kalff 1992; Rooth et al. 2003). Rates of litter decomposition, sediment accumulation, and cycling of carbon, nitrogen, and other nutrients can be altered (Joyce et al. 1992). Changes in dominant vegetation following invasions influence the food webs and flow of energy through aquatic systems (Gratton and Denno 2006; Kelly and Hawes 2005).

In evaluating these and other impacts of invasive species, it is important to bear in mind that both native and non-native species can act as ecosystem engineers in aquatic habitats (Crain and Bertness 2005; Duffy 2006; Posey et al. 1993). It is when non-native species have traits that are novel in the habitats they invade, i.e., when they occupy distinct ecological niches, that their impacts are potentially greatest (Moles et al. 2008; Ricciardi and Atkinson 2004). For example, invasive aquatic plants may occupy areas of habitat that would otherwise be unvegetated, produce substantially more biomass, or differ from native species with respect to growth form, phenology, tissue chemistry, position in the habitat, or other functional traits (Bolduan et al. 1994; Nichols and Shaw 1986; Posey et al. 1993). Under these circumstances, there is high potential for harm to aquatic habitats and associated human uses of these systems.

One of the major impacts of invasive aquatic plants is loss of plant diversity. Native macrophytes can be displaced by invasive species that are superior competitors for space, light, or nutrients (Gettys et al. 2014). Earlier phenology, more rapid growth, multiple reproductive mechanisms, or other "weedy" traits enable invasive macrophytes to outcompete native species for light (Woolf and Madsen 2003; Zedler and Kercher 2004). High stem densities and thick floating mats monopolize space, depriving native plants of suitable habitat (Hummel and Kiviat 2004; Schooler et al. 2006). Higher rates of nutrient uptake and utilization can also confer competitive advantages to invasive aquatic species over native species (Larkin et al. 2012b; Van et al. 1999).

The effects of aquatic invasive plant species on fish and other wildlife are of great concern. By reducing dissolved oxygen, dense growth of invasive plants can drive off or cause mortality of invertebrates and fish (Madsen 1997). Invasive plants can also have less acute effects that nonetheless deprive invertebrates, fish, and birds of suitable habitat, foraging resources, or nursery/breeding sites (Able and Hagan 2000; Glisson et al. 2015). However, because invasive plants may provide shelter and primary production that benefit certain animals, aquatic invasive plants do not necessarily decrease total invertebrate or fish diversity but may instead alter the community composition of these groups by favoring species adapted to higher stem densities or other differences in structure (Chick and Mlvor 1997; Engel 1987; Theel et al. 2007). Despite the clear value of macrophytes in general for fish and other organisms, the importance of particular plant species to particular animal species is generally not well resolved (Kovalenko et al. 2010). This makes it difficult to predict how aquatic plant invasions will ultimately affect animal communities. For example, canopy-producing invasive plants may enhance fish and wildlife habitat at early invasion stages by providing food, shelter, or substrate for macroinvertebrates but can eventually decrease these ecological services if the invader becomes overly abundant.

In addition to their broad environmental and ecological impacts, aquatic invasive plants can impair economic and recreational uses of aquatic systems. Dense mats of floating and submersed plants restrict navigation and impede water 
movement important for flood control, irrigation, and hydropower (Eiswerth and Johnson 2002; Penfound and Earle 1948). Recreational uses of lakes and rivers are disrupted when nuisance vegetation fouls boat motors or interferes with waterskiing, fishing, or wildlife viewing (Gettys et al. 2014). Decreased aesthetic value and interference with recreation reduce property values and tourism income (Charles and Dukes 2008; Horsch and Lewis 2009). While a dollar value is not easy to assign to the impacts of aquatic invasive plants, they are an important component of the estimated $\$ 120$ billion per year that invasive species of all types impose on the US economy (Pimentel et al. 2000).

The risk posed by invasive plants to a given aquatic habitat depends on geography, climate, propagule pressure from source populations, habitat characteristics that influence susceptibility to invasion, and management effort. Regional priorities for early detection and management are a moving target given that new species continue to be introduced to the United States or expand their ranges into new regions within the United States (Essl et al. 2011; Maki and Galatowitsch 2004). This uncertainty is compounded by climate change, which will enable certain aquatic invasive species to invade new areas and habitat types (Hellmann et al. 2008; Rahel and Olden 2008).

The degree to which a particular water body is susceptible to invasion depends on landscape and local factors. Locations closer to, or hydrologically connected to, source populations of aquatic invasive plants or those that are heavily used by boaters are more likely to receive seeds, fragments, or other propagules that can establish new populations (Buchan and Padilla 1999; Jackson and Pringle 2010). High levels of development activities by humans along shorelines or within watersheds act as disturbances that benefit opportunistic invasive species, for example, by altering hydrology, sedimentation, and nutrient loading (Vander Zanden and Olden 2008; Zedler and Kercher 2004).

The physical and chemical characteristics of a water body have a large influence on invasion risk. A fundamental characteristic of aquatic systems is their trophic state. In shallow lakes, differences in trophic status are associated with regime shifts between clear, macrophyte-dominated and turbid, phytoplankton-dominated alternative states (Scheffer 2004). Turbid states can support harmful algal blooms, but high light penetration in the desirable clear state can promote high productivity of submersed plants, including invasive species (Gettys et al. 2014; Scheffer 2004). Water depth affects light penetration and temperature, which are often limiting factors for growth of submersed invasive species (Barko and Smart 1981; Madsen et al. 1991). Thus, water drawdowns during droughts can lead to new infestations or accelerate expansion of existing infestations (Barrat-Segretain and Cellot 2007). Bathymetry and extent of the littoral zone determine potential habitat area available to submersed and emergent invasive species (Vis et al. 2003). Whether water flow is relatively static, moderate, or fast dictates which species are able to establish in a given water body (Madsen et al. 2001). Once established, sediment and water column characteristics-e.g., sediment texture and bulk density, nutrient availability, $\mathrm{pH}$, and oxidation-influence aquatic plants' fitness and productivity, potentially making the difference between an invasive species simply being present versus occurring at nuisance levels (Barko and Smart 1986; Fleming and Dibble 2015; Squires and Lesack 2003).

Ultimately, the impacts of aquatic invasive plants depend greatly on the diligence of aquatic and wetland monitoring and the degree of management responses directed against the invasive plants. Proactive efforts to prevent new invasions can be cost-effective relative to post-invasion, long-term management (Keller et al. 2008). Early detection and rapid response efforts can identify new infestations at stages when eradication may still be feasible (Anderson 2005). The use of existing invasive or prohibited plant lists and predictive models can help guide search efforts (Tamayo and Olden 2014), and advances in citizen science offer opportunities to develop large-scale detection networks for invasive plants (Crall et al. 2015). When invasive populations are already well established, sustained active management efforts can achieve effective control and conserve ecological structure and function (Kovalenko et al. 2010). However, large-scale or longterm management efforts may be complex and expensive. Thus, it is important to proceed with clearly defined goals, consult the most current control technologies, and implement a robust monitoring program to enable course corrections (Blossey 1999; Zedler 2005).

\subsubsection{Key Findings}

- In aquatic environments, invasive plants of various growth forms (floating, submersed, or emergent) can have large negative effects that can alter environmental conditions, ecosystem processes, plant and animal communities, and biological diversity. Compared to terrestrial habitats, freshwater aquatic habitats are disproportionately vulnerable to plant invasions.

- Aquatic invasive plant impacts generally increase as their abundance increases and when novel traits allow them to exploit distinct ecological niches. Mechanisms by which invasive plants affect aquatic systems include reducing sunlight penetration; altering water temperature, $\mathrm{pH}$, and nutrient concentrations; and reducing dissolved oxygen content.

- Invasive aquatic plants can greatly impair human uses of water bodies by restricting navigation; impeding water movement important for flood control, irrigation, or hydropower; disrupting recreational activities; and decreasing aesthetics, property values, and tourist income. 
- The physical and chemical characteristics of a water body, such as trophic state, depth, flow rate, and sediment characteristics greatly influence its vulnerability to invasive aquatic plants.

\subsubsection{Key Information Needs}

- Research to clarify the importance of particular plant species to particular animal species in aquatic systems is needed in order to better predict how aquatic plant invasions will affect animal communities.

- Understanding how climate change is likely to affect the ability of invasive aquatic species to invade new areas and habitat types would help improve regional efforts at early detection and management prioritization.

\subsection{Impacts of Invasive Animals in Aquatic Systems}

The introduction and establishment of invasive animals in aquatic environments is a key threat to the conservation of aquatic biodiversity and the provisioning of aquatic ecosystem services. The distribution of most aquatic animals is naturally constrained by drainage divides, but these barriers are frequently overcome by human-mediated movement of organisms among watersheds at many scales. Over 300 nonnative aquatic animals are established in North America, and these species represent a broad taxonomic spectrum, including mollusks, crustaceans, insects, fish, amphibians, reptiles, mammals, and microorganisms (Strayer 2010). These include species translocated from other continents or from one part of North America to another.

Not all non-native aquatic animals are invasive. Those non-native species recognized as having net negative effects on native biodiversity, ecosystem functioning, human health, or economic conditions are labeled as invasive (Sala et al. 2000), and the focus of this science synthesis is on species in this category. However, the effects of non-native species and human perceptions of these effects vary widely according to context. For example, brook trout (Salvelinus fontinalis) are the focus of conservation efforts as they decline in their native range in Eastern North America, but they negatively impact native fish populations when released as non-natives into the Rocky Mountains (Fausch et al. 2009) (Box 2.6, Fig. 2.8d). Non-native species, particularly sport fishes, may be esteemed by some segments of society for recreation, but considered invasive by others because of their negative ecological impacts. Some non-native species have been present in their non-native range for so long, and it is difficult to evaluate their effects. The Asian clam (Corbicula fluminea) was introduced into North America in the 1930s and is now the dominant bivalve there, but evidence of its negative effects is equivocal (Haag 2012; Strayer 1999). Still other non-native aquatic species appear to have no obvious negative effects, but in most cases these have not been studied well enough to determine what, if any, more subtle effects they may have on populations, communities, and ecosystems. Although our focus here is on aquatic invasive species with well-recognized impacts, it is essential to note that for
Fig. 2.8 Aquatic invasive species. (a) Zebra mussels (Dreissena polymorpha). (Photo courtesy of Randy Westbrooks, Invasive Plant Control, Inc., Bugwood.org);

(b) silver carp (Hypophthalmichthys molitrix). (Photo courtesy of Kate Gardiner, https://www. flickr.com/photos/ ennuiislife/4120213381); (c) rusty crayfish (Orconectes rusticus). (Photo courtesy of U.S. Geological Survey, Bugwood.org); (d) brook trout (Salvelinus fontinalis). (Photo courtesy of Michael Young, USDA Forest Service)
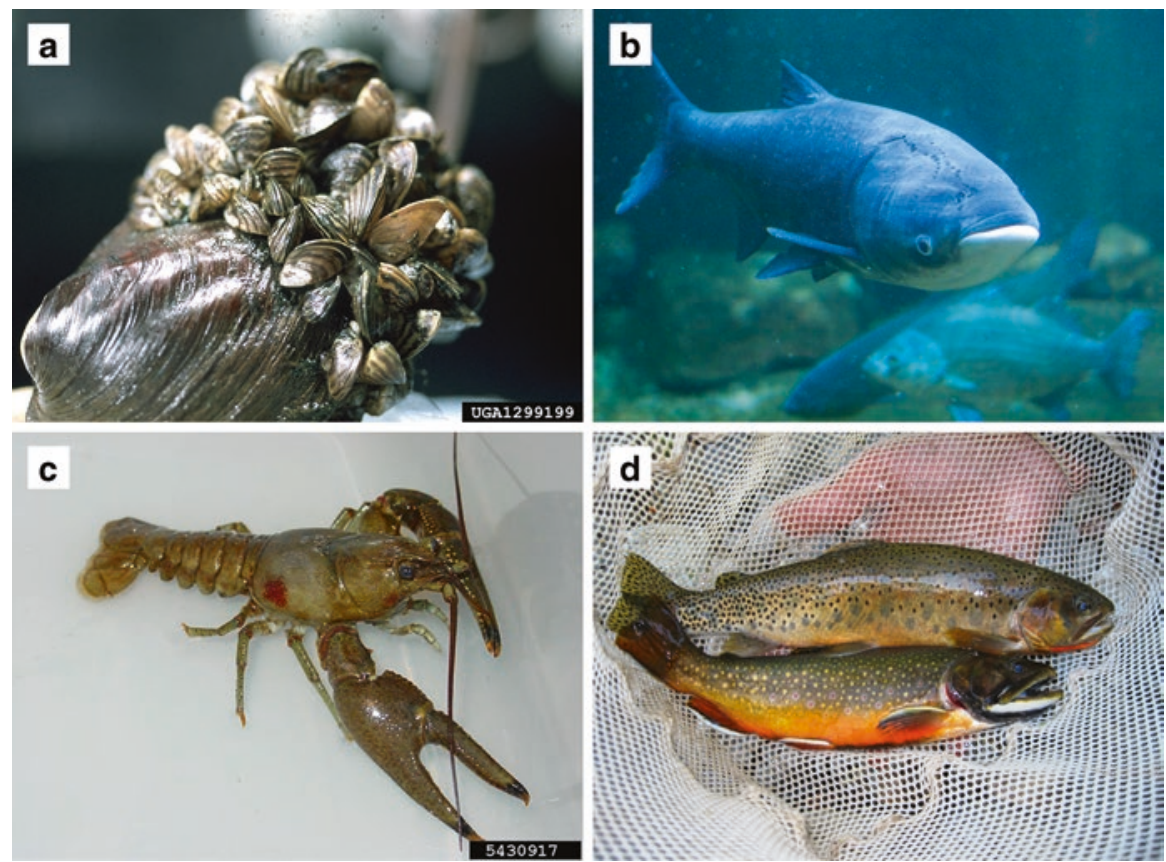


\section{Box 2.6 Aquatic Invasive Animal Species in Varying Contexts}

Aquatic invasive species include a wide range of taxa that have a variety of impacts. Taxa and impacts range from invasive bivalves, such as zebra mussels (Dreissena polymorpha) (Fig. 2.8a), which encrust native mollusks, interfering with their feeding and reproduction, to fish like silver carp (Hypophthalmichthys molitrix) (Fig. 2.8b), which have become the dominant species by biomass in some sections of North American rivers and can outcompete juvenile native fish for planktonic food resources. Zebra mussels and silver carp are not native to North America, originating from Northcentral Europe and Asia, respectively. In contrast, rusty crayfish (Orconectes rusticus) (Fig. 2.8c) and brook trout (Salvelinus fontinalis) (Fig. 2.8d, lower fish) are native to North America, but humans have moved them beyond their native ranges to other regions of the continent, where they have net negative impacts on the species native to those regions and on the aquatic ecosystems upon which native species depend. Rusty crayfish, native to the Southcentral United States, prey on, compete with, and hybridize with native crayfish in the Upper Midwest. Brook trout, native to the Eastern United States, compete with native cutthroat trout (Oncorhynchus clarkii) (Fig. 2.8d, upper fish) in the Western United States and prey on their offspring, contributing to concerns about native species' population viability.

many non-native aquatic species, additional research is needed to determine whether or not they are invasive.

The breadth of ecosystem effects of non-native species, from indeterminate to extreme, is illustrated in the Laurentian Great Lakes, where there are established populations of at least 90 non-native aquatic animals, most of which appear to have been introduced via commercial shipping (Holeck et al. 2004; Ricciardi 2001). Of the dozens of zooplankton species introduced into the Great Lakes, dramatic effects are demonstrated for only a few, and these effects vary spatially (e.g., Strecker and Arnott 2008). In contrast, zebra mussels and quagga mussels (Dreissena spp.) have radically transformed aquatic ecosystems in the Great Lakes region and throughout the rest of North America. Their effects include dramatic declines in phytoplankton and zooplankton and the nearelimination of native bivalves (Strayer et al. 1999) (Fig. 2.8a).
The distribution, abundance, and per capita effects (i.e., the effect per individual or per biomass unit, see Sect. 2.1.4) of non-native species in recipient habitats are the primary determinants of their ecosystem impacts (Parker et al. 1999; Ricciardi et al. 2013). When non-native species exploit previously unoccupied ecological niches, they may have particularly large effects. For example, epibenthic bivalves were absent in the Great Lakes prior to the introduction of Dreissena, which may have been a factor in their success. However, ecological novelty is not a prerequisite for becoming invasive. Rusty crayfish (Orconectes rusticus) displace native crayfish species to which they appear ecologically similar (Wilson et al. 2004) (Fig. 2.8c). Similarly, filterfeeding Asian carps can compose up to $80 \%$ of the overall fish biomass in midwestern rivers despite the historical presence of a variety of native filter-feeding fishes (e.g., gizzard shad (Dorosoma cepedianum) and paddlefish (Polyodon spathula)) (Sass et al. 2010) (Fig. 2.8b). Regardless of the factors that influence invasiveness (i.e., propensity of a species to cause net negative ecological impacts), the effects of aquatic invasive animal species can be manifested in several ways, including alteration of food webs or trophic relationships, habitat modification, and genetic hybridization.

Food web or trophic impacts can take a variety of forms. Many aquatic invasive animal species exert ecosystem effects by direct predation on native species. For example, nonnative lake trout (Salvelinus namaycush) consume juvenile native cutthroat trout (Oncorhynchus clarkii) in Yellowstone Lake (Ruzycki et al. 2003), and rusty crayfish consume eggs of native fish in the family Centrarchidae (Wilson et al. 2004). Invasive species also may parasitize native species (e.g., sea lamprey (Petromyzon marinus) parasitism of native lake trout in the Great Lakes (Lawrie 1970)) or as pathogens cause disease in native species (e.g., whirling disease, caused by Myxobolus cerebralis, infecting native salmonids (Gilbert and Granath 2003)). Invasive species can compete directly or indirectly for food with native organisms. Adult silver carp (Hypophthalmichthys molitrix) compete directly with juvenile yellow perch (Perca flavescens) for plankton, and reduction of phytoplankton abundance by Dreissena may be a major factor in the decline of native bivalves (Strayer 1999). The feeding behavior of invasive species may also have indirect, cascading effects on other organisms at progressively higher or lower trophic levels. An example of a trophic cascade occurred with the introduction of the opossum shrimp (Mysis diluviana) in Flathead Lake, MT (Ellis et al. 2011). Opossum shrimp preyed heavily on native zooplankton, causing significant declines in their abundance. In response to declining zooplankton, the native planktivorous fish that fed on them also declined, reducing the food available for piscivorous kokanee salmon (Oncorhynchus nerka), resulting in their decline. Ironically, kokanee are also intro- 
duced in this ecosystem, but they sustain a popular sport fishery and attract a concentration of migrating bald eagles (Haliaeetus leucocephalus), which feed on kokanee. After introduction of opossum shrimp, the crash in the kokanee population effectively ended the sport fishery and forced the eagles to relocate. A similarly complex outcome is invasional meltdown, in which invasions by one species facilitate invasions by others and, as a group, these non-native species can completely restructure faunal communities and trophic linkages. One example of this type of invasional meltdown is the establishment of round goby (Neogobius melanostomus) in the Great Lakes, which was facilitated by the presence of one of its preferred prey items from its native Ponto-Caspian range, zebra mussels (Dreissena polymorpha), which had previously invaded and become abundant in the ecosystem (Ricciardi 2001).

Invasive aquatic animals can modify the physical and chemical environment, which affects native species and ecosystems in various ways. Common carp (Cyprinus carpio) feed by rooting in soft substrates, and this behavior can increase water column turbidity and nutrient levels and result in a decrease in aquatic plants and macroinvertebrates (Parkos et al. 2003). Accumulations of Dreissena can transform areas of soft sediments into reefs of dead and living shells, which provide habitat for a different array of macroinvertebrates than would be present otherwise (Radziejewska et al. 2009). Waste excretion by dense aggregations of New Zealand mud snails (Potamopyrgus antipodarum) can dramatically raise nitrogen levels in otherwise low-productivity habitats (Hall et al. 2003). These changes can produce environmental conditions more conducive to non-native species than to native species. For example, common carp are adapted to turbid conditions that result from their feeding behavior, but bluegill (Lepomis macrochirus), smallmouth bass (Micropterus dolomieu), and other native centrarchids in these systems are visual feeders that may be affected negatively by increases in turbidity (Wolfe et al. 2009).

Hybridization between native and invasive species is also a widespread and growing concern (Perry et al. 2002). Hybridization poses little risk for species that are sufficiently divergent and have strong reproductive barriers, but closely related taxa are vulnerable to hybridization. Nonintrogressive hybridization, such as between invasive brook trout and federally listed bull trout (Salvelinus confluentus) in the Northwest (DeHaan et al. 2010), results in offspring that are largely inviable or infertile, causing reduced recruitment of the native species. Introgressive hybridization produces viable offspring that can spread non-native genes in later generations. Native Pecos pupfish (Cyprinodon pecosensis) in the Southwestern United States have been rapidly assimilated by invasive sheepshead minnow (Cyprinodon variegatus), resulting in loss of pure pupfish populations (Rosenfield et al. 2004). In some fish species, introgressive hybridization has led to range reductions of native species, with formerly occupied areas hosting parental forms of the non-native taxon or admixed individuals (McKelvey et al. 2016; Ward et al. 2012).

Humans experience a range of direct and indirect impacts of invasive aquatic animals. For example, Dreissena can clog municipal and industrial water intakes, and cyanobacterial blooms associated with high Dreissena densities cause taste and odor problems in water supplies (Vanderploeg et al. 2001). Dreissena can also interfere with recreational opportunities, including angling, boating, and swimming (Lovell et al. 2006; Rothlisberger et al. 2012). Reduced commercial fish stocks and increased costs of power generation have also been identified as impacts of Dreissena (Rothlisberger et al. 2012).

Attempts to control invasive species can have unintended negative consequences for native species and, as such, are an indirect ecological impact of aquatic invasive species. Mechanical or chemical control of invasive species, such as rotenone treatments for fish or chelated copper for Dreissena, may inadvertently harm populations of non-target organisms, such as amphibians and macroinvertebrates (Billman et al. 2011; Hamilton et al. 2009; Montz et al. 2010). Unnatural barriers designed to prevent the spread of invasive aquatic animals may interfere with the life cycle and habitat requirements of native fish species (Fausch et al. 2009). Aside from the harm they may cause to native species, control efforts are often unsuccessful, reinforcing the importance of prevention, early detection, and rapid response in managing biological invasions (Vander Zanden and Olden 2008).

The taxonomic diversity of invasive aquatic animals and the wide range of mechanisms by which they affect native ecosystems make it impossible to generalize what types of impacts are the most, or least, important, common, or severe. The effects of invasive aquatic animals are not only wide ranging as to type and severity; they are also manifest at multiple levels of biological organization, from genes to organisms to populations to communities to ecosystems. Human interests, including recreation, navigation, and water quality, are also affected negatively by the ecological changes caused by invasive aquatic animals. Additional research is needed to understand and quantify these ecological changes to better inform societal responses to aquatic invasive animals (Walsh et al. 2016).

\subsubsection{Key Findings}

- Invasive aquatic animals cause wide-ranging ecological and economic impacts. For example, invasive dreissenid mussels have transformed food webs in the Laurentian Great Lakes and elsewhere in North America. Their 
effects include dramatic declines in phytoplankton and zooplankton and the near-elimination of native bivalves.

- Types of impacts of invasive aquatic animals include alteration of food webs and trophic relationships, habitat modification, and genetic hybridization with native species.

- Many non-native aquatic animals have not been studied well enough to fully determine their ecological and economic impacts.

\subsubsection{Key Information Needs}

- Additional study is needed to clarify the role and effects of non-native animals in aquatic systems.

- For the vast majority of invasive aquatic animals, accurate assessments of ecological and economic impacts are needed.

- Studies of per capita effects of invasive aquatic animals have been more frequent than studies of population-level impacts. Additional work is needed for more invasive aquatic animals to scale information about per capita effects to the population and community levels.

\begin{abstract}
Acknowledgments We greatly appreciate preliminary reviews of this chapter by M.A. Barnes (Natural Resources Management, Texas Tech University), Y. Ortega (USDA FS Rocky Mountain Research Station), and R.C. Venette (USDA FS Northern Research Station and Director, Minnesota Invasive Terrestrial Plants and Pests Center, University of Minnesota, St. Paul). We sincerely thank K.D. Klepzig (formerly USDA FS Southern Research Station), J. Lockwood (Department of Ecology, Evolution, and Natural Resources, Rutgers University), and D.A. Herms (Department of Entomology, The Ohio State University), and four anonymous reviewers for formal reviews of the chapter. J.H. Cane (USDA ARS, Logan, Utah), N.M. Williams (UC Davis Department of Entomology and Nematology), and K. Ullmann (formerly Xerces Society for Invertebrate Conservation, Davis, CA) provided excellent reviews of the content on insect pollinators, whereas L.S. Bauer and T.M. Poland (both USDA FS Northern Research Station, Lansing, MI) provided reviews of content and images for the call-out example of the emerald ash borer.
\end{abstract}

Disclaimer Text The findings and conclusions in this publication are those of the authors and should not be construed to represent any official USDA or U.S. Government determination or policy.

\section{Literature Cited}

Able KW, Hagan SM (2000) Effects of common reed (Phragmites australis) invasion on marsh surface macrofauna: response of fishes and decapod crustaceans. Estuaries 23:633-646

Aizen MA, Harder LD (2009) The global stock of domesticated honey bees is growing slower than agricultural demand for pollination. Curr Biol 19:915-918

Allen CR, Epperson D, Garmestani A (2004) The impacts of fire ants on wildlife: a decade of research. Am Midl Nat 152:88-103

Allen CR, Uden DR, Johnson AR, Angeler DG (2015) Spatial modelling approaches for understanding and predicting the impacts of invasive alien species on native species and ecosystems. In: Venette
RC (ed) Pest risk modelling and mapping for invasive alien species. CAB International, New York, pp 162-170

Allison SD, Vitousek PM (2004) Rapid nutrient cycling in leaf litter from invasive plants in Hawai'i. Oecologia 141:612-619

Amarasekare P (1993) Potential impact of mammalian nest predators on endemic forest birds of western Mauna Kea, Hawaii. Conserv Biol 7:316-324

Anagnostakis SL (1987) Chestnut blight: the classical problem of an introduced pathogen. Mycologia 79:23-37

Anderson LW (2005) California's reaction to Caulerpa taxifolia: a model for invasive species rapid response. Biol Invasions 7:1003-1016

Artz DR, Allan MJ, Wardell GI, Pitts-Singer TL (2013) Nesting site density and distribution affect Osmia lignaria (Hymenoptera: Megachilidae) reproductive success and almond yield in a commercial orchard. Insect Conserv Divers 6:715-724

Ashton IW, Hyatt LA, Howe KM et al (2005) Invasive species accelerate decomposition and litter nitrogen loss in a mixed deciduous forest. Ecol Appl 15:1263-1272

Atkinson IAE (1989) Introduced animals and extinctions. In: Western D, Pearl MC (eds) Conservation for the twenty-first century. Oxford University Press, New York, pp 54-75

Aukema JE, McCullough DG, Von Holle B et al (2010) Historical accumulation of nonindigenous forest pests in the continental US. Bioscience 60:886-897

Aukema JE, Leung B, Kovacs K et al (2011) Economic impacts of nonnative forest insects in the continental United States. PLoS ONE 6(9):e24587

Baker HG (1974) The evolution of weeds. Annu Rev Ecol Syst 5:1-24

Baker HG, Stebbins GL (1965) The genetics of colonizing species. Academic, New York. 588 p

Baker PJ, Scowcroft PG, Ewel JJ (2009) Koa (Acacia koa) ecology and silviculture. General Technical Report PSW-GTR-211. Pacific Southwest Research Station. USDA Forest Service, Washington, DC

Balch JK, Bradley BA, D'Antonio CM, Gomez-Dans J (2013) Introduced annual grass increases regional fire activity across the arid western USA (1980-2009). Glob Chang Biol 19:173-183

Barber NA, Marquis RJ, Tori WP (2008) Invasive prey impacts the abundance and distribution of native predators. Ecology 89:2678-2683

Barko JW, Smart RM (1981) Comparative influences of light and temperature on the growth and metabolism of selected submersed freshwater macrophytes. Ecol Monogr 51:219-235

Barko JW, Smart RM (1986) Sediment-related mechanisms of growth limitation in submersed macrophytes. Ecology 67:1328-1340

Barney JN, Tekiela DR, Dollete ES, Tomasek BJ (2013) What is the "real" impact of invasive plant species? Front Ecol Environ $11: 322-329$

Barrat-Segretain M-H, Cellot B (2007) Response of invasive macrophyte species to drawdown: the case of Elodea sp. Aquat Bot 87:255-261

Bergstrom DM, Lucieer A, Kiefer K et al (2009) Indirect effects of invasive species removal devastate World Heritage Island. J Appl Ecol 46:73-81

Bevins SN, Pedersen K, Lutman MW et al (2014) Consequences associated with the recent range expansion of nonnative feral swine. Bioscience 64:291-299

Billman HG, St-Hilaire S, Kruse CG et al (2011) Toxicity of the piscicide rotenone to Columbia spotted frog and boreal toad tadpoles. Trans Am Fish Soc 140:919-927

Blackburn TM, Essl F, Evans T et al (2014) A unified classification of alien species based on the magnitude of their environmental impacts. PLoS Biol 12(5):e1001850

Blair AC, Nissen SJ, Brunk GR, Hufbauer RA (2006) A lack of evidence for an ecological role of the putative allelochemical $( \pm)$-catechin in spotted knapweed invasion success. J Chem Ecol 32:2327-2331

Blossey B (1999) Before, during and after: the need for long-term monitoring in invasive plant species management. Biol Invasions $1: 301-311$ 
Blossey B (2011) Enemy release hypothesis. In: Simberloff D, Rejmanek M (eds) Encyclopedia of biological invasions. University of California Press, Berkeley, pp 193-196

Blossey B, Notzold R (1995) Evolution of increased competitive ability in invasive nonindigenous plants: a hypothesis. J Ecol 83:887-889

Boettner GH, Elkinton JS, Boettner CJ (2000) Effects of a biological control introduction on three nontarget native species of saturniid moths. Conserv Biol 14:1798-1806

Bohlen PJ, Scheu S, Hale CM et al (2004) Non-native invasive earthworms as agents of change in northern temperate forests. Front Ecol Environ 2:427-435

Bolduan BR, Van Eeckhout GC, Quade HW, Gannon JE (1994) Potamogeton crispus - the other invader. Lake Reservoir Manag 10:113-125

Boyd IL, Freer-Smith PH, Gilligan CA, Godfray HCJ (2013) The consequence of tree pests and diseases for ecosystem services. Science 342:1235773. https://doi.org/10.1126/science.1235773

Boyte SP, Wylie BK (2017) Estimates of herbaceous annual cover in the sagebrush ecosystem. (May 1, 2017). U.S. Geological Survey data release. https://doi.org/10.5066/F7445JZ9

Brantley S, Ford CR, Vose JM (2013) Future species composition will affect forest water use after loss of eastern hemlock from southern Appalachian forests. Ecol Appl 23:777-790

Brantley ST, Miniat CF, Elliott KJ et al (2015) Changes to southern Appalachian water yield and stormflow after loss of a foundation species. Ecohydrology 8:518-528

Brasier CM (2001) Rapid evolution of introduced plant pathogens via interspecific hybridization. Bioscience 51:123-133

Brasier CM, Buck KW (2001) Rapid evolutionary changes in a globally invading fungal pathogen (Dutch elm disease). Biol Invasions 3:223-233

Broders K, Boraks A, Barbison L et al (2015) Recent insights into the pandemic disease butternut canker caused by the invasive pathogen Ophiognomonia clavigignenti-juglandacearum. For Pathol 45:1-8

Brooks ML, D'Antonio CM, Richardson DM et al (2004) Effects of invasive alien plants on fire regimes. Bioscience 54:677-688

Brown BJ, Mitchell RJ, Graham SA (2002) Competition for pollination between invasive species (purple loosestrife) and a native congener. Ecology 83:2328-2336

Buchan LA, Padilla DK (1999) Estimating the probability of longdistance overland dispersal of invading aquatic species. Ecol Appl 9:254-265

Buswell JM, Moles AT, Hartley S (2011) Is rapid evolution common in introduced plant species? J Ecol 99:214-224

Callaway RM, Aschehoug ET (2000) Invasive plants versus their new and old neighbors: a mechanism for exotic invasion. Science 290:521-523

Campbell TA, Long DB (2009) Feral swine damage and damage management in forested ecosystems. For Ecol Manag 257:2319-2326

Canadian Food Inspection Agency (2018) Areas regulated for the emerald ash borer. http://www.inspection.gc.ca/plants/plantpests-invasive-species/insects/emerald-ash-borer/areas-regulated/ eng/1347625322705/1367860339942

Cane JH (2003) Exotic non-social bees (Hymenoptera: Apoidea) in North America: ecological implications. In: Strickler KV, Cane JH (eds) For non-native crops, whence pollinators of the future? Thomas Say Publications in Entomology, Entomological Society of America, Lanham, pp 113-126

Cane JH (2018) Personal correspondence, email letter dated January 8, 2018 to Steven Seybold. On file with Seybold at U.S. Department of Agriculture, Forest Service, Pacific Southwest Research Station, 1731 Research Park Drive, Davis, CA 95618.

Cane JH, Tepedino VJ (2017) Gauging the effect of honey bee pollen collection on native bee communities. Conserv Lett 10:205-210

Caraco NF, Cole JJ (2002) Contrasting impacts of a native and alien macrophyte on dissolved oxygen in a large river. Ecol Appl $12: 1496-1509$
Carpenter SR, Lodge DM (1986) Effects of submersed macrophytes on ecosystem processes. Aquat Bot 26:341-370

Carroll SP, Hendry AP, Reznick DN, Fox CW (2007) Evolution on ecological time-scales. Funct Ecol 21:387-393

Chambers JC, Bradley BA, Brown CA et al (2013) Resilience to stress and disturbance, and resistance to Bromus tectorum L. invasion in cold desert shrublands of western North America. Ecosystems 17:360-375

Chambers JC, Beck JL, Bradford JB et al (2017) Science framework for conservation and restoration of the sagebrush biome: linking the Department of Interior's integrated rangeland fire management strategy to long-term strategic conservation actions. Part 1. Science basis and applications. RMRS-GTR-360. U.S. Department of Agriculture, Forest Service, Rocky Mountain Research Station, Fort Collins. $213 \mathrm{p}$

Charles H, Dukes JS (2008) Impacts of invasive species on ecosystem services. In: Nentwig W (ed) Biological invasions. Chapter 13, 1st edn. Springer, Berlin, pp 217-237

Chen Y, Evans JD, Smith IB, Pettis JS (2008) Nosema ceranae is a long-present and wide-spread microsporidian infection of the European honey bee (Apis mellifera) in the United States. J Invertebr Pathol 97:186-188

Chen Y, Whitehill JG, Bonello P, Poland TM (2011) Feeding by emerald ash borer larvae induces systemic changes in black ash foliar chemistry. Phytochemistry 72:1990-1998

Chick JH, Mlvor CC (1997) Habitat selection by three littoral zone fishes: effects of predation pressure, plant density and macrophyte type. Ecol Freshw Fish 6:27-35

Chornesky EA, Bartuska AM, Aplet GH et al (2005) Science priorities for reducing the threat of invasive species to sustainable forestry. Bioscience 55:335-348

Chupp AD, Battaglia LL (2014) Potential for host shifting in Papilio palamedes following invasion of laurel wilt disease. Biol Invasions 16:2639-2651

Clark KL, Skowronski N, Hom J (2010) Invasive insects impact forest carbon dynamics. Glob Chang Biol 16:88-101

Coates PS, Riccaa MA, Prochazkaa BG et al (2016) Wildfire, climate, and invasive grass interactions negatively impact an indicator species by reshaping sagebrush ecosystems. Proc Natl Acad Sci USA 113:12745-12,750

Cobb RC, Chan MN, Meentemeyer RK, Rizzo DM (2012) Common factors drive disease and coarse woody debris dynamics in forests impacted by sudden oak death. Ecosystems 15:242-255

Colautti RI, Lau JA (2015) Contemporary evolution during invasion: evidence for differentiation, natural selection, and local adaptation. Mol Ecol 24:1999-2017

Colautti RI, Ricciardi A, Grigorovich IA, MacIsaac HJ (2004) Is invasion success explained by the enemy release hypothesis? Ecol Lett 7:721-733

Colautti RI, Grigorovich IA, MacIsaac HJ (2006) Propagule pressure: a null model for biological invasions. Biol Invasions 8:1023-1037

Courchamp F, Langlais M, Sugihara G (1999) Control of rabbits to protect island birds from cat predation. Biol Conserv 89:219-225

Cox GW (2004) Alien species and evolution: the evolutionary ecology of exotic plants, animals, microbes, and interacting native species. Island Press, Washington, DC. 379 p

Cox JG, Lima SL (2006) Naiveté and an aquatic-terrestrial dichotomy in the effects of introduced predators. Trends Ecol Evol 21:674-680

Cox-Foster DL, Conlan S, Holmes EC (2007) A metagenomics survey of microbes in honey bee colony collapse disorder. Science 318:283-287

Crain CM, Bertness ND (2005) Community impacts of a tussock sedge: is ecosystem engineering important in benign habitats? Ecology 86:2695-2704

Crall A, Jarnevich C, Young N et al (2015) Citizen science contributes to our knowledge of invasive plant species distributions. Biol Invasions 17:2415-2427 
Croll DA, Maron JL, Estes JA et al (2005) Introduced predators transform subantarctic islands from grassland to tundra. Science 307:1959-1961

Crooks JA (2002) Characterizing ecosystem-level consequences of biological invasions: the role of ecosystem engineers. Oikos 97:153-166

Crowl TA, Cris TO, Parmenter RR et al (2008) The spread of invasive species and infectious disease as drivers of ecosystem change. Front Ecol Environ 6:238-246

D'Antonio CM, Vitousek PM (1992) Biological invasions by exotic grasses, the grass/fire cycle, and global change. Annu Rev Ecol Syst 23:63-87

Daehler CC (2003) Performance comparisons of co-occurring native and alien invasive plants: implications for conservation and restoration. Annu Rev Ecol Evol Syst 34:183-211

Dangremond EM, Pardini EA, Knight TM (2010) Apparent competition with an invasive plant hastens the extinction of an endangered lupine. Ecology 91:2261-2271

Daszak P, Cunningham AA, Hyatt AD (2000) Emerging infectious diseases of wildlife - threats to biodiversity and human health. Science 287:443-449

Davidson CB, Gottschalk KW, Johnson JE (2001) European gypsy moth (Lymantria dispar L.) outbreaks: a review of the literature. General Technical Report NE-278. USDA Forest Service, Northeastern Research Station, Newtown Square. $15 \mathrm{p}$

Davies KW, Boyd C, Beck JL et al (2011) Saving the sagebrush sea: an ecosystem conservation plan for big sagebrush plant communities. Biol Conserv 144:2573-2584

Davis MA (2009) Invasion biology. Oxford University Press on Demand

Davis MA, Grime JP, Thompson K (2000) Fluctuating resources in plant communities: a general theory of invasibility. J Ecol 88:528-534

Davis G, Lowrey L, Eckberg T, et al (2020) Notes on balsam woolly adelgid, Adelgespiceae (Ratzeburg, 1844) (Hemiptera: Adelgidae), range expansion in Idaho, Montana and Utah. Pan-Pacific Entomol 96:129-133

DeHaan PW, Schwabe LT, Ardren WR (2010) Spatial patterns of hybridization between bull trout, Salvelinus confluentus, and brook trout, Salvelinus fontinalis, in an Oregon stream network. Conserv Genet 11:935-949

Desurmont GA, Donoghue MJ, Clement WL, Agrawal AA (2011) Evolutionary history predicts plant defense against an invasive pest. Proc Natl Acad Sci USA 108:7070-7074

Dickie IA, Bolstridge N, Cooper JA, Peltzer DA (2010) Co-invasion by Pinus and its mycorrhizal fungi. New Phytol 187:475-484

Didham RK, Tylianakis JM, Gemmell NJ et al (2007) Interactive effects of habitat modification and species invasion on native species decline. Trends Ecol Evol 22:489-496

Dodds KJ, Orwig DA (2011) An invasive urban forest pest invades natural environments - Asian longhorned beetle in northeastern US hardwood forests. Can J For Res 41:1729-1742

Domec JC, Rivera LN, King JS et al (2013) Hemlock woolly adelgid (Adelges tsugae) infestation affects water and carbon relations of eastern hemlock (Tsuga canadensis) and Carolina hemlock (Tsuga caroliniana). New Phytol 199:452-463

Dorcas ME, Willson JD, Gibbons JW (2011) Can invasive Burmese pythons inhabit temperate regions of the southeastern United States? Biol Invasions 13:793-802

Dorcas ME, Willson JD, Reed RN et al (2012) Severe mammal declines coincide with proliferation of invasive Burmese pythons in Everglades National Park. Proc Natl Acad Sci USA 109:2418-2422

Duan JJ, Bauer LS, Abell KJ et al (2015) Population dynamics of an invasive forest insect and associated natural enemies in the aftermath of invasion: implications for biological control. J Appl Ecol 52:1246-1254

Duffy JE (2002) Biodiversity and ecosystem function: the consumer connection. Oikos 99:201-219
Duffy JE (2006) Biodiversity and the functioning of seagrass ecosystems. Mar Ecol Prog Ser 311:233-250

Ebbert SE, Byrd GV (2002) Eradications of invasive species to restore natural biological diversity on Alaska Maritime National Wildlife Refuge. Turning the tide: the eradication of invasive species. In: Veitch CR, Clout MN (eds) IUCN Invasive Species Specialist Group. Gland/Cambridge, pp 102-109

Eiswerth ME, Johnson WS (2002) Managing nonindigenous invasive species: insights from dynamic analysis. Environ Resour Econ 23:319-342

Ellis JD, Evans JD, Pettis J (2010) Colony losses, managed colony population decline, and Colony Collapse Disorder in the United States. J Agric Res 49:134-136

Ellis BK, Stanford JA, Goodman D et al (2011) Long-term effects of a trophic cascade in a large lake ecosystem. Proc Natl Acad Sci USA 108:1070-1075

Ellison AM, Bank MS, Clinton BD et al (2005) Loss of foundation species: consequences for the structure and dynamics of forested ecosystems. Front Ecol Environ 3:479-486

Ellshoff ZE, Gardner DE, Wikler C, Smith CW (1995) Annotated bibliography of the genus Psidium, with emphasis on P. cattleianum (strawberry guava) and P. guajava (common guava), forest weeds in Hawai 'i. Technical Report 95. Cooperative National Park Resources Studies Unit. University of Hawai' $i$, Manoa. 102 p

Elston JJ, Hewitt DG (2010) Intake of mast by wildlife in Texas and the potential for competition with wild boars. Southwest Nat 55:57-66

Elton CS (1958) The ecology of invasions by animals and plants. Methuen, London. $181 \mathrm{p}$

Emerald Ash Borer Information Network (2018) Map of EAB confirmations by state. http://www.emeraldashborer.info

Engel S (1987) The impact of submerged macrophytes on largemouth bass and bluegills. Lake Reservoir Manag 3:227-234

Engeman RM, Stevens A, Allen J et al (2007) Feral swine management for conservation of an imperiled wetland habitat: Florida's vanishing seepage slopes. Biol Conserv 134:440-446

Eskalen A, Stouthamer R, Lynch SC et al (2013) Host range of Fusarium dieback and its ambrosia beetle (Coleoptera: Scolytinae) vector in southern California. Plant Dis 97:938-951

Essl F, Dullinger S, Rabitsch W et al (2011) Socioeconomic legacy yields an invasion debt. Proc Natl Acad Sci USA 108:203-207

Estrada JA, Flory LS (2015) Cogongrass (Imperata cylindrica) invasions in the US: mechanisms, impacts, and threats to biodiversity. Glob Ecol Conserv 3:1-10

Evans J (1970) About nutria and their control. Resource Publication No. 86. U.S. Department of the Interior, Bureau of Sport Fisheries and Wildlife, Denver. $65 \mathrm{p}$

Fall MW, Avery ML, Campbell TA et al (2011) Rodents and other vertebrate invaders in the United States. In: Pimentel D (ed) Biological invasions: economic and environmental costs of alien plant, animal, and microbe species. CRC Press, Boca Raton, pp 381-410

Fausch KD, Rieman BE, Dunham JB et al (2009) Invasion versus isolation: trade-offs in managing native salmonids with barriers to upstream movement. Conserv Biol 23:859-870

Fleming JP, Dibble ED (2015) Ecological mechanisms of invasion success in aquatic macrophytes. Hydrobiologia 746:23-37

Fraedrich SW, Harrington TC, Rabaglia RJ et al (2008) A fungal symbiont of the redbay ambrosia beetle causes a lethal wilt in redbay and other Lauraceae in the southeastern United States. Plant Dis 92:215-224

Fraedrich SW, Harrington TC, Best GS (2015) Xyleborus glabratus attacks and systemic colonization by Raffaelea lauricola associated with dieback of Cinnamomum camphora in the southeastern United States. For Pathol 45:60-70

Franck P, Garnery L, Solignac M, Cornuet J-M (1998) The origin of west European subspecies of honeybees (Apis mellifera): new 
insights from microsatellite and mitochondrial data. Evolution 52:1119-1134

Fürst MA, McMahon DP, Osborne JL et al (2014) Disease associations between honeybees and bumblebees as a threat to wild pollinators. Nature 506:364-366

Gandhi KJK, Herms DA (2010a) Direct and indirect effects of alien insect herbivores on ecological processes and interactions in forests of eastern North America. Biol Invasions 12:389-405

Gandhi KJK, Herms DA (2010b) North American arthropods at risk due to widespread Fraxinus mortality caused by the alien emerald ash borer. Biol Invasions 12:1839-1846

Gettys LA, Haller WT, Petty DG (2014) Biology and control of aquatic plants. A best management practices handbook, 3rd edn. Aquatic Ecosystem Restoration Foundation, Marietta. 200 p

Gibbs J, Sheffield CS (2009) Rapid range expansion of the woolcarder bee, Anthidium manicatum (Linnaeus) (Hymenoptera: Megachilidae), in North America. J Kansas Entomol Soc 82:21-29

Gilbert MA, Granath WO (2003) Whirling disease of salmonid fish: life cycle, biology and disease. J Parasitol 89:658-667

Glisson WJ, Brady RS, Paulios AT et al (2015) Sensitivity of secretive marsh birds to vegetation condition in natural and restored wetlands in Wisconsin. J Wildl Manag 79:1101-1116

Goodell K (2008) Invasive exotic plant-bee interactions. In: James RR, Pitts-Singer TL (eds) Bees in agricultural ecosystems. Oxford University Press, New York, pp 166-183

Goulson D (2003) Effects of introduced bees on native ecosystems. Annu Rev Ecol Evol Syst 34:1-26

Gratton C, Denno RF (2006) Arthropod food web restoration following removal of an invasive wetland plant. Ecol Appl 16:622-631

Grime JP (1988) The C-S-R model of primary plant strategies-origins, implications and tests. In: Gottlieb LD, Jain SK (eds) Plant evolutionary biology. Springer, Dordrecht, pp 371-393

Grünwald NJ, Goss EM, Press CM (2008) Phytophthora ramorum: a pathogen with a remarkably wide host range causing sudden oak death on oaks and ramorum blight on woody ornamentals. Mol Plant Pathol 9:729-740

Grünwald NJ, Garbelotto M, Goss EM et al (2012) Emergence of the sudden oak death pathogen Phytophthora ramorum. Trends Microbiol 20:131-138

Guichón ML, Cassini MH (1999) Local determinants of coypu distribution along the Luján River, eastcentral Argentina. J Wildl Manag 63:895-900

Gunnell KL, Monaco TA, Call CA, Ransom CV (2010) Seedling interference and niche differentiation between crested wheatgrass and contrasting native Great Basin species. Rangel Ecol Manag 63:443-449

Guo Q, Fei S, Dukes JS et al (2015) A unified approach for quantifying invasibility and degree of invasion. Ecology 96:2613-2621

Haag WR (2012) North American freshwater mussels. Natural history, ecology and conservation. Cambridge University Press, New York, $540 \mathrm{p}$

Hall RO, Tank JL, Dybdahl MF (2003) Exotic snails dominate nitrogen and carbon cycling in a highly productive stream. Front Ecol Environ 1:407-411

Hall JS, Minnis RB, Campbell TA et al (2008) Influenza exposure in United States feral swine populations. J Wildl Dis 44:362-368

Hamilton BT, Moore SE, Williams TB et al (2009) Comparative effects of rotenone and antimycin on macroinvertebrate diversity in two streams in Great Basin National Park, Nevada. N Am J Fish Manag 29:1620-1635

Hammond RL, Crampton LH, Foster JT (2015) Breeding biology of two endangered forest birds on the island of Kauai, Hawaii. Condor 117:31-40

Hansen EM (2008) Alien forest pathogens: Phytophthora species are changing world forests. Boreal Environ Res 13:33-41
Hansen EM, Goheen DJ, Jules ES, Ullian B (2000) Managing PortOrford-cedar and the introduced pathogen Phytophthora lateralis. Plant Dis 84:4-14

Hanula JL, Horn S (2011a) Removing an exotic shrub from riparian forests increases butterfly abundance and diversity. For Ecol Manag 262:674-680

Hanula JL, Horn S (2011b) Removing an invasive shrub (Chinese privet) increases native bee diversity and abundance in riparian forests of the southeastern United States. Insect Conserv Divers $4: 275-283$

Harmon-Threatt A, Chin K (2016) Common methods for tallgrass prairie restoration and their potential effects on bee diversity. Nat Areas J 36:400-411

Harmon-Threatt A, Kremen C (2015) Bumble bees selectively use native and exotic species to maintain nutritional intake across highly variable and invaded local floral resource pools. Ecol Entomol 40:471-478

Harmon-Threatt A, Burns JH, Shemyakina LA, Knight TM (2009) Breeding system and pollination ecology of introduced plants compared to their native relatives. Am J Bot 96:1544-1550

Harper GA, Bunbury N (2015) Invasive rats on tropical islands: their population biology and impacts on native species. Glob Ecol Conserv 3:607-627

Havill NP, Montgomery ME, Keena M (2011) Hemlock woolly adelgid and its hemlock hosts: a global perspective. In: Onken B, Reardon $\mathrm{R}$ (eds) Implementation and status of biological control of the hemlock woolly adelgid. FHTET-2011-04. USDA Forest Service Forest Health Technology Enterprise Team, Morgantown, pp 3-14

Havill NP, Vieira LC, Salom SM (2014) Biology and control of hemlock woolly adelgid. FHTET-2014-05. USDA Forest Service, Forest Health Technology Enterprise Team, Morgantown. $21 \mathrm{p}$

Hefty AR, Aukema BH, Venette RC et al (2018) Reproduction of walnut twig beetle across the Juglandaceae. Biol Invasions 20:2141-2155

Hellmann JJ, Byers JE, Bierwagen BG, Dukes JS (2008) Five potential consequences of climate change for invasive species. Conserv Biol 22:534-543

Henry VG, Conley RH (1972) Fall foods of European wild hogs in the southern Appalachians. J Wildl Manag 36:854-860

Herms DA, McCullough DG (2014) Emerald ash borer invasion of North America: history, biology, ecology, impacts, and management. Annu Rev Entomol 59:13-30

Hierro JL, Callaway RM (2003) Allelopathy and exotic plant invasion. Plant Soil 256:29-39

Hierro JL, Maron JL, Callaway RM (2005) A biogeographical approach to plant invasions: the importance of studying exotics in their introduced and native range. $\mathrm{J}$ Ecol 93:5-15

Higes M, Martín-Hernández R, Botías C et al (2008) How natural infection by Nosema ceranae causes honeybee colony collapse. Environ Microbiol 10:2659-2669

Holeck KT, Mills EL, MacIsaac HJ et al (2004) Bridging troubled waters: biological invasions, transoceanic shipping, and the Laurentian Great Lakes. Bioscience 54:919-929

Holly DC, Ervin GN, Jackson CR et al (2009) Effect of an invasive grass on ambient rates of decomposition and microbial community structure: a search for causality. Biol Invasions 11:1855-1868

Holmes TP, Murphy EA, Royle DD (2005) The economic impacts of hemlock woolly adelgid on residential landscape values: Sparta, New Jersey case study. In: Onken B, Reardon R (eds) Third symposium on hemlock woolly adelgid in the eastern United States, 1-3 February 2005, Asheville, North Carolina 2005. U.S. Dep. Agric.Forest Service, Morgantown, pp 15-24

Holmes TP, Aukema JE, Von Holle B et al (2009) Economic impacts of invasive species in forests. Ann N Y Acad Sci 1162:18-38

Holt RD (1977) Predation, apparent competition, and the structure of prey communities. Theor Popul Biol 12:197-229 
Homan HJ, Johnson RJ, Thiele JR, Linz GM (2017) European starlings. Wildlife Damage Management Technical Series 13. USDA Animal and Plant Health Inspection Service, Fort Collins, $26 \mathrm{p}$

Horsch EJ, Lewis DJ (2009) The effects of aquatic invasive species on property values: evidence from a quasi-experiment. Land Econ 85:391-409

Houston DR (1994) Major new tree disease epidemics: beech bark disease. Annu Rev Phytopathol 32:75-87

Houston DB, Schreiner EG (1995) Alien species in national parks: drawing lines in space and time. Conserv Biol 9:204-209

Hu J, Angeli S, Schuetz S et al (2009) Ecology and management of exotic and endemic Asian longhorned beetle Anoplophora glabripennis. Agric For Entomol 11:359-375

Hudson JR, Hanula JL, Horn S (2013) Removing Chinese privet from riparian forests still benefits pollinators five years later. Biol Conserv 167:355-362

Hughes MA, Smith JA, Ploetz RC et al (2015) Recovery plan for laurel wilt on redbay and other forest species caused by Raffaelea lauricola and disseminated by Xyleborus glabratus. Plant Health Progr. https://doi.org/10.1094/PHP-RP-15-0017

Hulcr J, Dunn RR (2011) The sudden emergence of pathogenicity in insect-fungus symbioses threatens naive forest ecosystems. Proc R Soc Lond B Biol Sci 278:2866-2873

Hulme PE, Pyšek P, Jarošík V et al (2013) Bias and error in understanding plant invasion impacts. Trends Ecol Evol 28:212-218

Hummel M, Kiviat E (2004) Review of world literature on water chestnut with implications for management in North America. J Aquat Plant Manag 42:17-27

Iannone BV, Oswalt CM, Liebhold AM et al (2015) Region-specific patterns and drivers of macroscale forest plant invasions. Divers Distrib 21:1181-1192

Inch S, Ploetz R, Held B, Blanchette R (2012) Histological and anatomical responses in avocado, Persea americana, induced by the vascular wilt pathogen, Raffaelea lauricola. Botany 90:627-635

Jackson CR, Pringle CM (2010) Ecological benefits of reduced hydrologic connectivity in intensively developed landscapes. Bioscience 60:37-46

Jacobi WR, Koski RD, Harrington TC et al (2007) Association of Ophiostoma novo-ulmi with Scolytus schevyrewi (Scolytidae) in Colorado. Plant Dis 91:245-247

Jacobi WR, Koski RD, Negrón JF (2013) Dutch elm disease pathogen transmission by the banded elm bark beetle Scolytus schevyrewi (Curculionidae subfamily Scolytinae). For Pathol 43:232-237

Jay MT, Cooley M, Carychao D et al (2007) Escherichia coli O157: $\mathrm{H} 7$ in feral swine near spinach fields and cattle, central California coast. Emerg Infect Dis 13:1908-1911

Jones CG, Lawton JH, Shachak M (1996) Organisms as ecosystem engineers. In: Samson FB, Knopf FL (eds) Ecosystem management. Springer, New York, pp 130-147

Jones HP, Tershy BR, Zavaleta ES et al (2008) Severity of the effects of invasive rats on seabirds: a global review. Conserv Biol 22:16-26

Jones HP, Holmes ND, Butchard SHM et al (2016) Invasive mammal eradication on islands results in substantial conservation gains. Proc Natl Acad Sci USA 113:4033-4038

Joyce J, Langeland K, Van T, Vandiver V (1992) Organic sedimentation associated with hydrilla management. J Aquat Plant Manag 30:20-23

Jules ES, Kauffman MJ, Ritts WD, Carroll AL (2002) Spread of an invasive pathogen over a variable landscape: a nonnative root rot on Port Orford cedar. Ecology 83:3167-3181

Kaller MD, Kelso WE (2006) Swine activity alters invertebrates and microbial communities in a coastal plain watershed. Am Midl Nat 156:163-177

Keane RM, Crawley MJ (2002) Exotic plant invasions and the enemy release hypothesis. Trends Ecol Evol 17:164-170
Keller RP, Frang K, Lodge DM (2008) Preventing the spread of invasive species: economic benefits of intervention guided by ecological predictions. Conserv Biol 22:80-88

Kelly DJ, Hawes I (2005) Effects of invasive macrophytes on littoralzone productivity and foodweb dynamics in a New Zealand highcountry lake. J N Am Benthol Soc 24:300-320

Kenis M, Auger-Rozenberg MA, Roques A et al (2009) Ecological effects of invasive alien insects. Biol Invasions 11:21-45

Kerns BK, Day MA (2017) The importance of disturbance by fire and other abiotic and biotic factors in driving cheatgrass invasion varies based on invasion stage. Biol Invasions 19:1853-1862

Kimoto T (2018) Personal correspondence, email letter dated January 10, 2018 to Steven Seybold. On file with Seybold at U.S. Department of Agriculture, Forest Service, Pacific Southwest Research Station, 1731 Research Park Drive, Davis, CA 95618

Klee J, Besana AM, Genersch E et al (2007) Widespread dispersal of the microsporidian Nosema ceranae, an emergent pathogen of the western honey bee, Apis mellifera. J Invertebr Pathol 96:1-10

Koenig WD, Walters EL, Liebhold AM (2011) Effects of gypsy moth outbreaks on North American woodpeckers. Condor 113:352-361

Koenig WD, Liebhold AM, Bonter DN et al (2013) Effects of the emerald ash borer invasion on four species of birds. Biol Invasions 15:2095-2103

Koh I, Lonsdorf EV, Williams NM (2015) Modeling the status, trends, and impacts of wild bee abundance in the United States. Proc Natl Acad Sci USA 113:140-145

Kolar CS, Lodge DM (2001) Progress in invasion biology: predicting invaders. Trends Ecol Evol 16:199-204

Kosola KR, Dickmann DI, Paul EA, Parry D (2001) Repeated insect defoliation effects on growth, nitrogen acquisition, carbohydrates, and root demography of poplars. Oecologia 129:65-74

Kovacs KF, Haight RG, McCullough DG et al (2010) Cost of potential emerald ash borer damage in US communities, 2009-2019. Ecol Econ 69:569-578

Kovalenko KE, Dibble ED, Slade JG (2010) Community effects of invasive macrophyte control: role of invasive plant abundance and habitat complexity. J Appl Ecol 47:318-328

Kuebbing SE, Simberloff D, Nuñez MA (2013) Current mismatch between research and conservation efforts: the need to study cooccurring invasive plant species. Biol Conserv 160:121-129

Landers JL, Van Lear DH, Boyer WD (1995) The longleaf pine forests of the Southeast: requiem or renaissance? J For 93:39-44

Lankau RA, Nuzzo V, Spyreas G, Davis AS (2009) Evolutionary limits ameliorate the negative impact of an invasive plant. Proc Natl Acad Sci USA 106:15362-15367

Larkin DJ, Freyman MJ, Lishawa SC et al (2012a) Mechanisms of dominance by the invasive hybrid cattail Typha $\times$ glauca. Biol Invasions 14:65-77

Larkin DJ, Lishawa SC, Tuchman NC (2012b) Appropriation of nitrogen by the invasive cattail Typha $\times$ glauca . Aquat Bot 100:62-66

Lau JA (2006) Evolutionary responses of native plants to novel community members. Evolution 60:56-63

Lawrie AH (1970) The sea lamprey in the Great Lakes. Trans Am Fish Soc 99:766-775

Lees AC, Bell DJ (2008) A conservation paradox for the 21st century: the European wild rabbit Oryctolagus cuniculus, an invasive alien and an endangered native species. Mammal Rev 38:304-320

Li S-P, Cadotte MW, Meiners SJ et al (2015) The effects of phylogenetic relatedness on invasion success and impact: deconstructing Darwin's naturalisation conundrum. Ecol Lett 18:1285-1292

Liao C, Peng R, Luo Y et al (2008) Altered ecosystem carbon and nitrogen cycles by plant invasion: a meta-analysis. New Phytol 177:706-714

Liebhold AM, MacDonald WL, Bergdahl D, Mastro VC (1995) Invasion by exotic forest pests: a threat to forest ecosystems. For Sci 41:1-49 
Lippincott CL (2000) Effects of Imperata cylindrica (L.) Beauv. (Cogongrass) invasion on fire regime in Florida sandhill (USA). Nat Areas J 20:140-149

Liu H, Stiling P (2006) Testing the enemy release hypothesis: a review and meta-analysis. Biol Invasions 8:1535-1545

Liu H, Bauer LS, Gao R et al (2003) Exploratory survey for the emerald ash borer, Agrilus planipennis (Coleoptera: Buprestidae), and its natural enemies in China. Great Lakes Entomol 36:191-204

Lockwood JL, Burkhalter JC (2015) The impact of invasive species on wildlife habitat. In: Morrison ML, Mathewson HA (eds) Wildlife habitat conservation. Johns Hopkins University Press in association with The Wildlife Society, Baltimore, pp 102-114

Lockwood JL, Hoopes MF, Marchetti MP (2007) Invasion ecology. Wiley, New York. 304 p

Lodge DM, Stein RA, Brown KM et al (1998) Predicting impact of freshwater exotic species on native biodiversity: challenges in spatial scaling. Aust Ecol 23:53-67

Loo JA (2009) Ecological impacts of non-indigenous invasive fungi as forest pathogens. Biol Invasions 11:81-96

Loope LL, Hamann O, Stone CP (1988) Comparative conservation biology of oceanic archipelagoes: Hawaii and the Galapagos. Bioscience 38:272-282

Lorence DH, Sussman RW (1986) Exotic species invasion into Mauritius wet forest remnants. J Trop Ecol 2:147-162

Lovell SJ, Stone SF, Fernandez L (2006) The economic impacts of aquatic invasive species: a review of the literature. Agric Resour Econ Rev 35:195-208

Lovett GM, Canham CD, Arthur MA et al (2006) Forest ecosystem responses to exotic pests and pathogens in eastern North America. Bioscience 56:395-405

Lovett GM, Arthur MA, Weathers KC, Griffin JM (2010) Long-term changes in forest carbon and nitrogen cycling caused by an introduced pest/pathogen complex. Ecosystems 13:1188-1200

Lucardi RD, Wallace LE, Ervin GN (2014) Invasion success in Cogongrass (Imperata cylindrica): a population genetic approach exploring genetic diversity and historical introductions. Invasive Plant Sci Manag 7:59-75

Lynch SC, Twizeyimana M, Mayorquin JS et al (2016) Identification, pathogenicity and abundance of Acremonium pembeum sp. nov. and Graphium euwallaceae sp. nov.- two newly discovered mycangial associates of the polyphagous shot hole borer (Euwallacea sp.) in California. Mycologia 108:313-329

MacDonald GE (2004) Cogongrass (Imperata cylindrica) - biology, ecology, and management. Crit Rev Plant Sci 23:367-380

MacDougall AS, Turkington R (2005) Are invasive species the drivers or passengers of change in degraded ecosystems? Ecology 86:42-55

MacDougall AS, Gilbert B, Levine JM (2009) Plant invasions and the niche. J Ecol 97:609-615

Mack RN (1981) Invasion of Bromus tectorum L. into western North America: an ecological chronicle. Agro-Ecosystems 7:145-165

Mack RN, Simberloff D, Lonsdale WM et al (2000) Biotic invasions: causes, epidemiology, global consequences, and control. Ecol Appl 10:689-710

Madsen JD (1997) Methods for management of nonindigenous aquatic plants. In: Luken JO, Thieret JW (eds) Assessment and management of plant invasions, 1st edn. Springer, New York, pp 145-171

Madsen JD, Hartleb CF, Boylen CW (1991) Photosynthetic characteristics of Myriophyllum spicatum and six submersed aquatic macrophyte species native to Lake George, New York. Freshw Biol 26:233-240

Madsen JD, Chambers PA, James WF et al (2001) The interaction between water movement, sediment dynamics and submersed macrophytes. Hydrobiologia 444:71-84

Maehr DS, Belden RC, Land ED, Wilkins L (1990) Food habits of panthers in southwest Florida. J Wildl Manag 54:420-423
Maestas JD, Campbell SB, Chambers JC et al (2016) Tapping soil survey information for rapid assessment of sagebrush ecosystem resilience and resistance. Rangelands 38:120-128

Maki K, Galatowitsch S (2004) Movement of invasive aquatic plants into Minnesota (USA) through horticultural trade. Biol Conserv 118:389-396

Maloy OC (2001) White pine blister rust. Plant Health Progr. https:// doi.org/10.1094/PHP-2001-0924-01-HM

Maron JL, Estes JA, Croll DA et al (2006) An introduced predator alters Aleutian Island plant communities by thwarting nutrient subsidies. Ecol Monogr 76:3-24

Marshall JM, Smith EL, Mech R, Storer AJ (2013) Estimates of Agrilus planipennis infestation rates and potential survival of ash. Am Midl Nat 169:179-193

Matsuura M, Yamane S (1990) Biology of the Vespine wasps. SpringerVerlag, Berlin, pp 1-323

McClure ML, Burdett CL, Farnsworth ML et al (2015) Modeling and mapping the probability of occurrence of invasive wild pigs across the contiguous United States. PLoS ONE 10(8):e0133771

McKelvey KS, Young MK, Wilcox TM et al (2016) Patterns of hybridization among cutthroat trout and rainbow trout in northern Rocky Mountain streams. Ecol Evol 6:688-706

McKinney ML, Lockwood JL (1999) Biotic homogenization: a few winners replacing many losers in the next mass extinction. Trends Ecol Evol 14:450-453

Meng XJ, Lindsay DS, Sriranganathan N (2009) Wild boars as sources for infectious diseases in livestock and humans. Philos Trans R Soc Lond B Biol Sci 364:2697-2707

Mercader RJ, McCullough DG, Storer AJ et al (2016) Estimating local spread of recently established emerald ash borer, Agrilus planipennis, infestations and the potential to influence it with a systemic insecticide and girdled ash trees. For Ecol Manag 366:87-97

Millar JG, Hanks LM (2017) Chemical ecology of cerambycids. In: Wang Q (ed) Cerambycidae of the world: biology and pest management. CRC Press/Taylor \& Francis Group, Boca Raton, pp 161-208

Miller SR, Gaebel R, Mitchell RJ, Arduser M (2002) Occurrence of two species of old world bees, Anthidium manicatum and A. oblongatum (Apoidea: Megachilidae), in northern Ohio and southern Michigan. Great Lakes Entomol 35:65-69

Mills LS, Soulé ME, Doak DF (1993) The keystone-species concept in ecology and conservation. Bioscience 43:219-224

Mitchell RF, Reagel PF, Wong JCH et al (2015) Cerambycid beetle species with similar pheromones are segregated by phenology and minor pheromone components. J Chem Ecol 41:431-440

Moles AT, Gruber MAM, Bonser SP (2008) A new framework for predicting invasive plant species. J Ecol 96:13-17

Montgomery ME, Bentz SE, Olsen RT (2009) Evaluation of hemlock (Tsuga) species and hybrids for resistance to Adelges tsugae (Hemiptera: Adelgidae) using artificial infestation. J Econ Entomol 102:1247-1254

Montz GR, Hirsch J, Rezanka R, Staples DF (2010) Impacts of copper on a lotic benthic invertebrate community: response and recovery. $\mathrm{J}$ Freshw Ecol 25:575-587

Moorhouse TP, Macdonald DW (2015) Are invasives worse in freshwater than terrestrial ecosystems? Wiley Interdiscip Rev Water 2:1-8

Morales CL, Traveset A (2009) A meta-analysis of impacts of alien vs. native plants on pollinator visitation and reproductive success of coflowering native plants. Ecol Lett 12:716-728

Morin RS, Liebhold AM (2015) Invasive forest defoliator contributes to the impending downward trend of oak dominance in eastern North America. Forestry. https://doi.org/10.1093/forestry/cpv053

Moron D, Lenda M, Skorka P et al (2009) Wild pollinator communities are negatively affected by invasion of alien goldenrods in grassland landscapes. Biol Conserv 142:1322-1332 
Moser WK, Barnard EL, Billings RF et al (2009) Impacts of nonnative invasive species on US forests and recommendations for policy and management. J For 107:320-327

Myers JH, Simberloff D, Kuris AM, Carey JR (2000) Eradication revisited: dealing with exotic species. Trends Ecol Evol 15:316-320

National Invasive Species Council [NISC] (2005) Five-year review of Executive Order 13112 on Invasive Species. National Invasive Species Council, Department of the Interior, Office of the Secretary (OS/SIO/NISC), Washington, DC. 44 p. https://www.invasivespeciesinfo.gov/laws/execorder.shtml\#sec1

National Research Council [NRC] (2007) Chapter 3: Causes of pollinator declines and potential threats. In: Committee on the Status of Pollinators in North America. Status of pollinators in North America. The National Academies Press, Washington, DC, pp 75-103. http:// www.nap.edu/read/11761/chapter/5\#90. Accessed 10 Jan 2018

Negrón JF, Witcosky JJ, Cain RJ et al (2005) The banded elm bark beetle: a new threat to elms in North America. Am Entomol 51:84-94

Nichols SA, Shaw BH (1986) Ecological life histories of the three aquatic nuisance plants, Myriophyllum spicatum, Potamogeton crispus and Elodea canadensis. Hydrobiologia 131:3-21

Niemelä P, Mattson WJ (1996) Invasion of North American forests by European phytophagous insects. Bioscience 46:741-753

Noonburg EG, Byers JE (2005) More harm than good: when invader vulnerability to predators enhances impact on native species. Ecology 86:2555-2560

Noss RF, LaRoe ET, III, Scott JM (1995) Endangered ecosystems of the United States: a preliminary assessment of loss and degradation, vol. 28. US Department of the Interior, National Biological Service, Washington, DC. 95 p. http://sciences.ucf.edu/biology/king/wpcontent/uploads/sites/106/2011/08/Noss-et-al-1995.pdf

Olden JD, Poff NL, Douglas MR et al (2004) Ecological and evolutionary consequences of biotic homogenization. Trends Ecol Evol 19:18-24

Orrock JL, Witter MS, Reichman OJ (2008) Apparent competition with an exotic plant reduces native plant establishment. Ecology 89:1168-1174

Orrock JL, Holt RD, Baskett ML (2010) Refuge-mediated apparent competition in plant-consumer interactions. Ecol Lett 13:11-20

Ortega YK, McKelvey KS, Six DL (2006) Invasion of an exotic forb impacts reproductive success and site fidelity of a migratory songbird. Oecologia 149:340-351

Ortega YK, Greenwood L, Callaway RM, Pearson DE (2014) Differential response of congeneric consumers to an exotic food resource: who gets the novel resource prize? Biol Invasions 16:1757-1767

Paolucci EM, MacIsaac HJ, Ricciardi A (2013) Origin matters: alien consumers inflict greater damage on prey populations than do native consumers. Divers Distrib 19:988-995

Parker IM, Gilbert GS (2004) The evolutionary ecology of novel plantpathogen interactions. Annu Rev Ecol Evol Syst 35:675-700

Parker IM, Simberloff D, Lonsdale WM et al (1999) Impact: toward a framework for understanding the ecological effects of invaders. Biol Invasions 1:3-19

Parkos JJ III, Santucci VJ Jr, Wahl DH (2003) Effects of adult common carp (Cyprinus carpio) on multiple trophic levels in shallow mesocosms. Can J Fish Aquat Sci 60:182-192

Pearson DE (2009) Invasive plant architecture alters trophic interactions by changing predator abundance and behavior. Oecologia 159:549-558

Pearson DE (2010) Trait- and density- mediated indirect interactions initiated by an exotic plant autogenic ecosystem engineer. Am Nat 176:394-403

Pearson DE, Callaway RM (2008) Weed biocontrol insects reduce native plant recruitment through second-order apparent competition. Ecol Appl 18:1489-1500
Pearson DE, Ortega YK, Eren O, Hierro JL (2016a) Quantifying "apparent" impact and distinguishing impact from invasiveness in multispecies plant invasions. Ecol Appl 26:162-173

Pearson DE, Ortega YK, Runyon J, Butler J (2016b) Secondary invasion: the bane of weed management. Biol Conserv 197:8-17

Pejchar L, Mooney HA (2009) Invasive species, ecosystem services and human well-being. Trends Ecol Evol 24:497-504

Penfound WT, Earle TT (1948) The biology of the water hyacinth. Ecol Monogr 18:447-472

Pennington T (2014) Egeria. In: Gettys LA, Haller WT, Bellaud M (eds) Biology and control of aquatic plants. A best management practices handbook, 3rd edn. Aquatic Ecosystem Restoration Foundation, Marietta, pp 129-134

Perry WL, Lodge DM, Feder JL (2002) Importance of hybridization between indigenous and nonindigenous freshwater species: an overlooked threat to North American biodiversity. Syst Biol 51:255-275

Petticrew EL, Kalff J (1992) Water flow and clay retention in submerged macrophyte beds. Can J Fish Aquat Sci 49:2483-2489

Pfitsch WA, Bliss LC (1985) Seasonal forage availability and potential vegetation limitations to a mountain goat population, Olympic National Park. Am Midl Nat 113:109-121

Phillips BL, Brown GP, Shine R (2010) Evolutionarily accelerated invasions: the rate of dispersal evolves upwards during the range advance of cane toads. J Evol Biol 23:2595-2601

Pimentel D (2011) Environmental and economic costs associated with alien invasive species in the United States. In: Pimentel D (ed) Biological invasions: economic and environmental costs of alien plant, animal, and microbe species. CRC Press, Boca Raton, pp 411-430

Pimentel D, Lach L, Zuniga R, Morrison D (2000) Environmental and economic costs of nonindigenous species in the United States. Bioscience 50:53-65

Pimentel D, Zuniga R, Morrison D (2005) Update on the environmental and economic costs associated with alien-invasive species in the United States. Ecol Econ 52:273-288

Pitts-Singer TL, Cane JH (2011) The alfalfa leafcutting bee, Megachile rotundata: the world's most intensively managed solitary bee. Annu Rev Entomol 56:221-237

Poland TM, Chen Y, Koch J, Pureswaran D (2015a) Review of the emerald ash borer (Coleoptera: Buprestidae), life history, mating behaviours, host plant selection, and host resistance. Can Entomol 147:252-262

Poland TM, Ciaramitaro TM, Emery M et al (2015b) Submergence of black ash logs to control emerald ash borer and preserve wood for American Indian basketmaking. Agric For Entomol 17:412-420

Posey MH, Wigand C, Stevenson JC (1993) Effects of an introduced aquatic plant, Hydrilla verticillata, on benthic communities in the upper Chesapeake Bay. Estuar Coast Shelf Sci 37:539-555

Powell KI, Krakos KN, Knight TM (2011) Comparing the reproductive success and pollination biology of an invasive plant to its rare and common native congeners: a case study in the genus Cirsium (Asteraceae). Biol Invasions 13:905-917

Pyšek P, Richardson DM (2008) Traits associated with invasiveness in alien plants: where do we stand? In: Nentwig W (ed) Biological invasions. Ecological studies (analysis and synthesis), vol 193. Springer, Berlin/Heidelberg, pp 97-125

Pyšek P, Jarošík V, Hulme PE et al (2012) A global assessment of invasive plant impacts on resident species, communities and ecosystems: the interaction of impact measures, invading species' traits and environment. Glob Chang Biol 18:1725-1737

Rabenold KN, Fauth PT, Goodner BW et al (1998) Response of avian communities to disturbance by an exotic insect in spruce-fir forests of the southern Appalachians. Conserv Biol 12:177-189

Radziejewska T, Fenske C, Wawrzyniak-Wydrowska B et al (2009) The zebra mussel (Dreissena polymorpha) and the benthic community 
in a coastal Baltic lagoon: another example of enhancement? Mar Ecol 30(Suppl. 1):138-150

Rahel FJ, Olden JD (2008) Assessing the effects of climate change on aquatic invasive species. Conserv Biol 22:521-533

Redman AM, Scriber JM (2000) Competition between the gypsy moth, Lymantria dispar, and the northern tiger swallowtail, Papilio canadensis: interactions mediated by host plant chemistry, pathogens, and parasitoids. Oecologia 125:218-228

Reinhart KO, Callaway RM (2006) Soil biota and invasive plants. New Phytol 170:445-457

Rejmánek M (1996) A theory of seed plant invasiveness: the first sketch. Biol Conserv 78:171-181

Rejmánek M, Richardson DM (1996) What attributes make some plant species more invasive? Ecology 77:1655-1661

Ricciardi A (2001) Facilitative interactions among aquatic invaders: is an "invasional meltdown" occurring in the Great Lakes? Can J Fish Aquat Sci 58:2513-2525

Ricciardi A (2003) Predicting the impacts of an introduced species from its invasion history: an empirical approach applied to zebra mussel invasions. Freshw Biol 48:972-981

Ricciardi A, Atkinson SK (2004) Distinctiveness magnifies the impact of biological invaders in aquatic ecosystems. Ecol Lett 7:781-784

Ricciardi A, Hoopes MF, Marchetti MP, Lockwood JL (2013) Progress toward understanding the ecological impacts of nonnative species. Ecol Monogr 83:263-282

Rieder JP, Newbold TAS, Ostoja SM (2010) Structural changes in vegetation coincident with annual grass invasion negatively impacts sprint velocity of small vertebrates. Biol Invasions 12:2429-2439

Rizzo DM, Garbelotto M, Davidson JM et al (2002) Phytophthora ramorum as the cause of extensive mortality of Quercus spp. and Lithocarpus densiflorus in California. Plant Dis 86:205-214

Rizzo DM, Garbelotto M, Hansen EM (2005) Phytophthora ramorum: Integrative research and management of an emerging pathogen in California and Oregon forests. Annu Rev Phytopathol 43:309-335

Rodgers L, Derksen A, Pernas T (2014) Expansion and impact of laurel wilt in the Florida Everglades. Fla Entomol 97:1247-1250

Rodriguez LF (2006) Can invasive species facilitate native species? Evidence of how, when, and why these impacts occur. Biol Invasions 8:927-939

Roemer GW, Donlan CJ, Courchamp F (2002) Golden eagles, feral pigs, and insular carnivores: how exotic species turn native predators into prey. Proc Natl Acad Sci USA 99:791-796

Rooth JE, Stevenson JC, Cornwall JC (2003) Increased sediment accretion rates following invasion by Phragmites australis: the role of litter. Estuaries 26(2B):475-483

Rosenfield JA, Nolasco S, Lindauer S et al (2004) The role of hybrid vigor in the replacement of Pecos pupfish by its hybrids with sheepshead minnow: genetic homogenization of endemic pupfish. Conserv Biol 18:1589-1598

Rothlisberger JD, Finnoff DC, Cooke RM, Lodge DM (2012) Shipborne nonindigenous species diminish Great Lakes ecosystem services. Ecosystems 15:1-15

Russo L, Nichol C, Shea K (2016) Pollinator floral provisioning by a plant invader: quantifying beneficial effects of detrimental species. Divers Distrib 22:189-198

Ruzycki JR, Beauchamp DA, Yule DL (2003) Effects of introduced lake trout on native cutthroat trout in Yellowstone Lake. Ecol Appl $13: 23-37$

Sakai AK, Allendorf FW, Holt JS et al (2001) The population biology of invasive species. Annu Rev Ecol Syst 32:305-332

Sala OE, Chapin FS, Armesto JJ et al (2000) Global biodiversity scenarios for the year 2100. Science 287:1770-1774

Sass GG, Cook TR, Irons KS et al (2010) A mark-recapture population estimate for invasive silver carp (Hypophthalmichthys molitrix) in the La Grange Reach, Illinois River. Biol Invasions 12:433-436

Scheffer M (2004) Ecology of shallow lakes. Kluwer Academic Publishers, Dortdrecht. 357 p
Schmitz DC, Schardt JD, Leslie AJ et al (1993) The ecological impact and management history of three invasive alien aquatic plant species in Florida. In: McKnight BN (ed) Biological pollution: The control and impact of invasive exotic species. Proceedings of a symposium held at Indianapolis, Indiana, USA, 25-26 October 1991. Indiana Academy of Science, Indianapolis, pp 173-194

Schmitz OJ, Beckerman AP, O’Brien KM (1997) Behaviorally mediated trophic cascades: effects of predation risk on food web interactions. Ecology 78:1388-1399

Schmitz OJ, Krivan V, Ovadia O (2004) Trophic cascades: the primacy of trait-mediated indirect interactions. Ecol Lett 7:153-163

Schooler SS, McEvoy PB, Coombs EM (2006) Negative per capita effects of purple loosestrife and reed canary grass on plant diversity of wetland communities. Divers Distrib 12:351-363

Schroeder MA, Aldridge CL, Apa AD et al (2004) Distribution of sagegrouse in North America. Condor 106:363-376

Schwartz MW, Hoeksema JD, Gehring CA et al (2006) The promise and the potential consequences of the global transport of mycorrhizal fungal inoculum. Ecol Lett 9:501-515

Seabloom EW, Borer ET, Buckley YM et al (2015) Plant species' origin predicts dominance and response to nutrient enrichment and herbivores in global grasslands. Nat Commun 6:7710

Seward NW, VerCauteren KC, Witmer GW, Engeman RM (2004) Feral swine impacts on agriculture and the environment. Sheep Goat Res J 19:34-40

Seybold SJ, Penrose RL, Graves AD (2016) Invasive bark and ambrosia beetles in California Mediterranean forest ecosystems. In: Paine TD, Lieutier F (eds) Insects and diseases of Mediterranean forest systems. Springer, Cham, pp 583-662

Simberloff D (1995) Why do introduced species appear to devastate islands more than mainland areas? Pac Sci 49:87-97

Simberloff D, Von Holle B (1999) Positive interactions of nonindigenous species: Invasional meltdown? Biol Invasions 1:21-32

Sinclair WA, Campana RJ (eds) (1978) Dutch elm disease: perspectives after 60 years. Northeast Regional Research Publication, Agriculture 8(5). Cornell University Agricultural Experiment Station, Ithaca. $52 \mathrm{p}$

Smart MD (2015) The influence of mid-continent agricultural land use on the health and survival of commercially managed honey bee (Apis mellifera L.) colonies. Ph.D. Dissertation, University of Minnesota, St. Paul. 245 p

Smith CS, Barko J (1990) Ecology of Eurasian watermilfoil. J Aquat Plant Manag 28:55-64

Smith GF, Nicholas NS (1998) Patterns of overstory composition in the fir and fir-spruce forests of the Great Smoky Mountains after balsam woolly adelgid infestation. Am Midl Nat 139:340-352

Snyder JR (2015) Ecological implications of laurel wilt infestation on Everglades tree islands, southern Florida. U.S. Geological Survey Open-File Report 2014-1225. 18 p. https://doi.org/10.3133/ ofr20141225. (10 January 2018)

Snyder WE, Evans EW (2006) Ecological effects of invasive arthropod generalist predators. Annu Rev Ecol Evol Syst 37:95-122

Sousa WTZ (2011) Hydrilla verticillata (Hydrocharitaceae), a recent invader threatening Brazil's freshwater environments: a review of the extent of the problem. Hydrobiologia 669:1-20

Space JC (2013) USDA Forest Service, Pacific Island Ecosystems at Risk (PIER). Online resource at http://www.hear.org/pier/

Squires MM, Lesack LFW (2003) The relation between sediment nutrient content and macrophyte biomass and community structure along a water transparency gradient among lakes of the Mackenzie Delta. Can J Fish Aquat Sci 60:333-343

State of Hawaii (2011) Final Environmental Assessment: Biological control of strawberry guava by its natural control agent for preservation of native forests in the Hawaiian Islands. 712 p. http://oeqc2. doh.hawaii.gov/EA_EIS_Library/2011-11-08-ST-FEA-BiocontrolStrawberry-Guava.pdf 
Stinson KA, Campbell SA, Powell JR et al (2006) Invasive plant suppresses the growth of native tree seedlings by disrupting belowground mutualisms. PLoS Biol 4(5):e0040140

Stohlgren TJ, Barnett DT, Kartesz JT (2003) The rich get richer: patterns of plant invasions in the United States. Front Ecol Environ $1: 11-14$

Stout JC, Morales CL (2009) Ecological impacts of invasive alien species on bees. Apidologie 40:388-409

Strange JP, Koch JB, Gonzalea VH et al (2011) Global invasion by Anthidium manicatum (Linnaeus) (Hymenoptera: Megachilidae): assessing potential distribution in North America and beyond. Biol Invasions 13:2115-2133

Strauss SY, Lau JA, Carroll SP (2006) Evolutionary responses of natives to introduced species: what do introductions tell us about natural communities? Ecol Lett 9:357-374

Strayer DL (1999) Effects of alien species on freshwater mollusks in North America. J N Am Benthol Soc 18:74-98

Strayer DL (2010) Alien species in fresh waters: ecological effects, interactions with other stressors, and prospects for the future. Freshw Biol 55:152-174

Strayer DL, Caraco NF, Cole JJ et al (1999) Transformation of freshwater ecosystems by bivalves: a case study of zebra mussels in the Hudson River. Bioscience 49:19-27

Strecker AL, Arnott SE (2008) Invasive predator, Bythotrephes, has varied effects on ecosystem function in freshwater lakes. Ecosystems 11:490-503

Stroud RK, Roelke ME (1980) Salmonella meningoencephalomyleitis in a northern fur seal (Callorhinus ursinus). J Wildl Dis 16:15-18

Suda J, Meyerson LA, Leitch IJ, Pyšek P (2015) The hidden side of plant invasions: the role of genome size. New Phytol 205:994-1007

Suding KN, Stanley Harpole W, Fukami T et al (2013) Consequences of plant-soil feedbacks in invasion. J Ecol 101:298-308

Swank WG, Petrides GA (1954) Establishment and food habits of the nutria in Texas. Ecology 35:172-176

Sydnor TD, Bumgardner M, Todd A (2007) The potential economic impacts of emerald ash borer (Agrilus planipennis) on Ohio, US, communities. Arboricult Urban For 33:48-54

Takahashi M, Giambelluca TW, Mudd RG et al (2011) Rainfall partitioning and cloud water interception in native forest and invaded forest in Hawai'i Volcanoes National Park. Hydrol Process 25:448-464

Tamayo M, Olden JD (2014) Forecasting the vulnerability of lakes to aquatic plant invasions. Invasive Plant Sci Manag 7:32-45

Tepedino VJ, Bradley BA, Griswold TL (2008) Might flowers of invasive plants increase native bee carrying capacity? Intimations from Capitol Reef National Park. Utah Nat Areas J 28:44-50

Terry PJ, Adjers G, Akobundo IO et al (1997) Herbicides and mechanical control of Imperata cylindrica as a first step in grassland rehabilitation. Agrofor Syst 36:151-179

Theel HJ, Dibble ED, Madsen JD (2007) Differential influence of a monotypic and diverse native aquatic plant bed on a macroinvertebrate assemblage; an experimental implication of exotic plant induced habitat. Hydrobiologia 600:77-87

Thiele J, Kollmann J, Markussen B (2010) Impact assessment revisited: improving the theoretical basis for management of invasive alien species. Biol Invasions 12:2025-2035

Tilman D (1982) Resource competition and community structure. Princeton University Press, Princeton. 296 p

Tingley MW, Orwig DA, Field R, Motzkin G (2002) Avian response to removal of a forest dominant: consequences of hemlock woolly adelgid infestations. J Biogeogr 29:1505-1516

Tisserat N, Cranshaw W, Leatherman D et al (2009) Black walnut mortality in Colorado caused by the walnut twig beetle and thousand cankers disease. Plant Health Progr. https://doi.org/10.1094/ PHP-2009-0811-01-RS

Tripodi A, Hardin T (2020) New Pest Response Guidelines. Vespa mandarinia Asian Giant Hornet, United States Department of
Agriculture Animal and Plant Health Inspection Service. https:// cms.agr.wa.gov/WSDAKentico/Documents/PP/PestProgram/ Vespa_mandarinia_NRPG-10Feb2020-(002).pdf

Trussell GC, Ewanchuk PJ, Matassa CM (2006) Habitat effects on the relative importance of trait-and density-mediated indirect interactions. Ecol Lett 9:1245-1252

U.S. Department of Interior (2015) An Integrated Rangeland Fire Management Strategy. Final Report to the Secretary of the Interior. https://www.forestsandrangelands.gov/rangeland/ documents/IntegratedRangelandFireManagementStrategy_ FinalReportMay2015.pdf

Umeda C, Esaklen A, Paine TD (2016) Polyphagous shot hole borer and Fusarium dieback in California. In: Paine TD, Lieutier F (eds) Insects and diseases of Mediterranean forest systems. Springer, Cham, pp 757-767

Urcelay C, Longo S, Geml J et al (2017) Co-invasive exotic pines and their ectomycorrhizal symbionts show capabilities for wide distance and altitudinal range expansion. Fungal Ecol 25:50-58

USDA Forest Service (2013) Forest Service national strategic framework for invasive species management. FS-1017. United States Department of Agriculture, Forest Service, Washington, DC, 35 p. http://www.fs.fed.us/foresthealth/publications/Framework_for_ Invasive_Species_FS-1017.pdf

Utley C, Nguyen T, Roubtsova T et al (2013) Susceptibility of walnut and hickory species to Geosmithia morbida. Plant Dis 97:601-607

Van Driesche R, Reardon R (2014) The use of classical biological control to preserve forests in North America. Publication FHTET-2013-2. USDA Forest Service, Forest Health Technology Enterprise Team, Morgantown, $414 \mathrm{p}$

Van Driesche RG, Carruthers RI, Center T et al (2010) Classical biological control for the protection of natural ecosystems. Biol Control $54:$ S2-S33

Van Lear DH, Carroll WD, Kapeluck PR, Johnson R (2005) History and restoration of the longleaf pine-grassland ecosystem: implications for species at risk. For Ecol Manag 211:150-165

Van TK, Wheeler GS, Center TD (1999) Competition between Hydrilla verticillata and Vallisneria americana as influenced by soil fertility. Aquat Bot 62:225-233

Vander Zanden MJ, Olden JD (2008) A management framework for preventing the secondary spread of aquatic invasive species. Can J Fish Aquat Sci 65:1512-1522

Vanderploeg HA, Liebig JR, Carmichael WW et al (2001) Zebra mussel (Dreissena polymorpha) selective filtration promoted toxic Microcystis blooms in Saginaw Bay (Lake Huron) and Lake Erie. Can J Fish Aquat Sci 58:1208-1221

Vanderwerf EA, Smith DG (2002) Effects of alien rodent control on demography of the O'ahu'Elepaio, an endangered Hawaiian forest bird. Pac Conserv Biol 8:73-81

vanEngelsdorp D, Meixner MD (2010) A historical review of managed honey bee populations in Europe and the United States and the factors that may affect them. J Invertebr Pathol 103:S80-S95

vanEngelsdorp D, Evans JD, Saegerman C et al (2009) Colony collapse disorder: a descriptive study. PLoS ONE 4(8):e6481

Vargas RI, Stark JD, Nishida T (1990) Population dynamics, habitat preference, and seasonal distribution patterns of oriental fruit fly and melon fly in an agricultural area. Environ Entomol 19:1820-1828

Vellend M, Harmon LJ, Lockwood JL et al (2007) Effects of exotic species on evolutionary diversification. Trends Ecol Evol 22:481-488

Verhoeven KJ, Biere A, Harvey JA, Van Der Putten WH (2009) Plant invaders and their novel natural enemies: who is naïve? Ecol Lett 12:107-117

Villamagna AM, Murphy BR (2010) Ecological and socio-economic impacts of invasive water hyacinth (Eichhornia crassipes): a review. Freshw Biol 55:282-298

Vis C, Hudon C, Carignan R (2003) An evaluation of approaches used to determine the distribution and biomass of emergent and sub- 
merged aquatic macrophytes over large spatial scales. Aquat Bot 77:187-201

Vitousek PM (1990) Biological invasions and ecosystem processes: towards an integration of population biology and ecosystem studies. Oikos 57:7-13

Vose JM, Wear DN, Mayfield AE, Nelson CD (2013) Hemlock woolly adelgid in the southern Appalachians: control strategies, ecological impacts, and potential management responses. For Ecol Manag 291:209-219

Wagner DL (2007) Emerald ash borer threatens ash-feeding Lepidoptera. News Lepidopterists' Soc 49:10-11

Wagner DL, Todd KJ (2015) Ecological impacts of emerald ash borer. In: Van Driesche RG, Reardon RC (eds) Biology and control of the emerald ash borer. FHTET-2014-09. USDA Forest Service, Forest Health Technology Enterprise Team, Morgantown, pp 15-63

Wagner DL, Van Driesche RG (2010) Threats posed to rare or endangered insects by invasions of nonnative species. Annu Rev Entomol 55:547-568

Walsh JR, Carpenter SR, Vander Zanden MJ (2016) Invasive species triggers a massive loss of ecosystem services through a trophic cascade. Proc Natl Acad Sci USA 113:4081-4085

Walther GR, Roques A, Hulme PE et al (2009) Alien species in a warmer world: risks and opportunities. Trends Ecol Evol 24:686-693

Ward JL, Blum MJ, Walters DM et al (2012) Discordant introgression in a rapidly expanding hybrid swarm: hybridization and biological invasion in shiners. Evol Appl 5:380-392

Waring GH, Loope LL, Medeiros AC (1993) Study on use of alien versus native plants by nectarivorous forest birds on Maui, Hawaii. Auk 110:917-920

Werner EE, Peacor SD (2003) A review of trait-mediated indirect interactions in ecological communities. Ecology 84:1083-1100

Whisenant SG (1990) Changing fire frequencies on Idaho's Snake River plains: ecological and management implications. In: McArthur ED, Romney EM, Smith SD, Tueller PT (eds) Proceedings from the symposium on cheatgrass invasion, shrub dieoff and other aspects of shrub biology and management, General Technical Report INT-276. USDA Forest Service, Ogden, pp 5-7

White EM, Wilson JC, Clarke AR (2006) Biotic indirect effects: a neglected concept in invasion biology. Divers Distrib 12:443-455

Whitney KD, Gabler CA (2008) Rapid evolution in introduced species, 'invasive traits' and recipient communities: challenges for predicting invasive potential. Divers Distrib 14:569-580

Williams GR, Tarpy DR, vanEngelsdorp D et al (2010) Colony collapse disorder in context. Bioessays 32:845-846
Williams NM, Cariveau D, Winfree R, Kremen C (2011) Bees in disturbed habitats use, but do not prefer, alien plants. Basic Appl Ecol 12:332-341

Wilson KA, Magnuson JJ, Lodge DM et al (2004) A long-term rusty crayfish (Orconectes rusticus) invasion: dispersal patterns and community change in a north temperate lake. Can J Fish Aquat Sci 61:2255-2266

Witmer GW, Sanders RB, Taft AC (2003) Feral swine - are they a disease threat to livestock in the United States? USDA National Wildlife Research Center - Staff Publications. Paper 292. http:// digitalcommons.unl.edu/icwdm_usdanwrc/292

Wolfe BE, Klironomos JN (2005) Breaking new ground: soil communities and exotic plant invasion. Bioscience 55:477-487

Wolfe MD, Santucci VJ, Einfalt LM, Wahl DH (2009) Effects of common carp on reproduction, growth, and survival of largemouth bass and bluegills. Trans Am Fish Soc 138:975-983

Woolf TE, Madsen JD (2003) Seasonal biomass and carbohydrate allocation patterns in southern Minnesota curlyleaf pondweed populations. J Aquat Plant Manag 41:113-118

Wootton JT (1994) The nature and consequences of indirect effects in ecological communities. Annu Rev Ecol Evol Syst 25:443-466

Wootton JT, Emmerson M (2005) Measurement of interaction strength in nature. Annu Rev Ecol Evol Syst 36:419-444

Work TT, McCullough DG (2000) Lepidopteran communities in two forest ecosystems during the first gypsy moth outbreaks in northern Michigan. Environ Entomol 29:884-900

Xiong S, Nilsson C (1999) The effects of plant litter on vegetation: a meta-analysis. J Ecol 87:984-994

Yokomizo H, Possingham HP, Thomas MB, Buckley YM (2009) Managing the impact of invasive species: the value of knowing the density-impact curve. Ecol Appl 19:376-386

Zavaleta ES, Hobbs RJ, Mooney HA (2001) Viewing invasive species removal in a whole-ecosystem context. Trends Ecol Evol 16:454-459

Zavortink TJ, Shanks SS (2008) Anthidium manicatum (Linnaeus) (Hymenoptera: Megachilidae) in California. Pan-Pac Entomol $84: 238-241$

Zedler JB (2005) Ecological restoration: guidance from theory. San Franc Estuary Watershed Sci 3(2):31 pp. http://repositories.cdlib. org/jmie/sfews/vol3/iss2/art4

Zedler JB, Kercher S (2004) Causes and consequences of invasive plants in wetlands: opportunities, opportunists, and outcomes. Crit Rev Plant Sci 23:431-452

Zenni RD, Nuñez MA (2013) The elephant in the room: the role of failed invasions in understanding invasion biology. Oikos 122:801-815

Open Access This chapter is licensed under the terms of the Creative Commons Attribution 4.0 International License (http://creativecommons. org/licenses/by/4.0/), which permits use, sharing, adaptation, distribution and reproduction in any medium or format, as long as you give appropriate credit to the original author(s) and the source, provide a link to the Creative Commons license and indicate if changes were made.

The images or other third party material in this chapter are included in the chapter's Creative Commons license, unless indicated otherwise in a credit line to the material. If material is not included in the chapter's Creative Commons license and your intended use is not permitted by statutory regulation or exceeds the permitted use, you will need to obtain permission directly from the copyright holder.

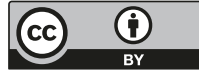

